\title{
Austronesian influence and Transeurasian ancestry in Japanese
}

\section{A case of farming/language dispersal}

\author{
Martine Robbeets \\ Max Planck Institute for the Science of Human History \\ martine_robbeets@hotmail.com
}

\begin{abstract}
In this paper, I propose a hypothesis reconciling Austronesian influence and Transeurasian ancestry in the Japanese language, explaining the spread of the Japanic languages through farming dispersal. To this end, I identify the original speech community of the Transeurasian language family as the Neolithic Xinglongwa culture situated in the West Liao River Basin in the sixth millennium вс. I argue that the separation of the Japanic branch from the other Transeurasian languages and its spread to the Japanese Islands can be understood as occurring in connection with the dispersal of millet agriculture and its subsequent integration with rice agriculture. I further suggest that a prehistorical layer of borrowings related to rice agriculture entered Japanic from a sister language of proto-Austronesian, at a time when both language families were still situated in the Shandong-Liaodong interaction sphere.
\end{abstract}

\section{Keywords}

Transeurasian - Austronesian - Japanese - farming/language dispersal hypothesis borrowing - inheritance

\section{Introduction}

The Japanese language displays remarkable similarities with the Transeurasian - traditionally called "Altaic"-languages as well as with the Austronesian languages. This fact has given rise to a certain polarization in classification attempts between scholars who try to relate Japanese to the Transeurasian lan-

(C) MARTINE ROBBEETS, 2017 | DOI: $10.1163 / 22105832-00702005$

This is an open access article distributed under the terms of the prevailing CC-BY-NC license 
guages on the one hand (e.g., Miller, 1971; Vovin, 1994; Starostin et al., 2003; Robbeets, 2005) and others who try to relate it to the Austronesian languages on the other hand (e.g., Kawamoto, 1985; Benedict, 199o). Attempts to make the extremes meet are found in consensus approaches such as the idea that Japanese is a mixed language (e.g., Murayama, 1976; Maher, 1996; Sakiyama, 1996) or that it is a language of Transeurasian ancestry on an Austronesian substratum (e.g., foreword by Poppe in Miller, 1971).

As Hudson (1996) points out, there is a serious archaeological problem with proposing a linguistic connection between Japanese and Austronesian because there is no evidence that a substantial number of Austronesian speakers reached Japan in the prehistoric Jōmon (10,00о BC-100о BC) or Yayoi (1000 BC-300 AD) periods. Although Hudson (2012) recently identified the Neolithic cultures of the Southern Ryukyuan Sakishima Islands as Austronesian, he stresses that there is no evidence for the movement of people across the gap between the Southern Sakishima and the Northern Amami-Okinawa Islands, which marks the boundary between the Austronesian and Jōmon cultural zones. Thus, although the linguistic similarities between Japanese and the Austronesian languages have often been viewed in light of a prehistoric connection between Jōmon people and Austronesian populations, interdisciplinary support for such a connection appears to be missing.

Bringing together data from linguistics and archaeology, this paper suggests an alternative way to reconcile prehistoric Austronesian influence with Transeurasian ancestry in Japanese. It proposes that Japanese underwent Austronesian influence at a time when the so-called "Japanic" ancestor of Japanese was still spoken on the eastern coast of the Asian continent, neighbored by a sister language of proto-Austronesian, called "para-Austronesian." ${ }^{1}$

In this paper, the spread of the Transeurasian languages in general and Japanic in particular is viewed through the lens of the Farming/Language Dispersal Hypothesis. This hypothesis, proposed by Renfrew (1987), Bellwood and Renfrew (2002), Diamond and Bellwood (2003) and Bellwood (2005, 2011), posits that many of the world's major language families owe their dispersal to the adoption of agriculture: on becoming farmers, populations grew in number, moved into wider territories and displaced the languages of preexisting

1 I distinguish between Japanic languages on the one hand and Japonic languages on the other. The term "Japanic" is used by Janhunen (1996: $77-78,80-81$ ) in reference to the historical varieties of the Japanese language spoken on the Korean Peninsula in addition to those spoken on the Japanese Islands. By contrast, the label "Japonic," coined by Serafim (1999), is restricted to the insular variety, the language family composed of Mainland Japanese and the Ryukyuan languages. 
hunter-gatherers. The specific interpretation of this hypothesis proposed here is that the Transeurasian homeland correlates with the early Neolithic Xinglongwa culture (6200-3750 BC), situated in Southern Manchuria from the seventh millennium BC onwards, while the homeland of Japanic is situated on the Liaodong Peninsula between the third and second millennium BC, with its speakers adopting rice agriculture from a para-Austronesian population within the Liaodong-Shandong interaction sphere. Sagart first hypothesized that a form of pre-Austronesian was spoken on the Shandong Peninsula during that time (Sagart, 1995), and he suggested that the linguistic ancestors of the Japanese acquired rice cultivation from speakers of an eastern language within the Sino-Tibetan-Austronesian macrofamily with whom they were once in contact (Sagart, 2011).

This paper has the following organization. Section 2 briefly reviews the nature of the linguistic similarities between Japanese on the one hand and the Transeurasian and Austronesian languages on the other, drawing a distinction between genealogically and areally induced similarities. Section 3 attempts to link the major demographic pulses associated with the establishment of agriculture in Northeast Asia with the dispersal of the languages under discussion. Section 4 examines common linguistic items linked to subsistence that are shared between Japanese and Transeurasian or Austronesian languages. The concluding Section 5 brings the findings together in a Farming/Language Dispersal Hypothesis for the dispersal of the Transeurasian languages and the peopling of Japan.

\section{Linguistic similarities in general}

\subsection{Japanese and the Transeurasian languages}

The term "Transeurasian" refers to a large group of geographically adjacent languages, illustrated in Fig. 1. They stretch from the Pacific in the East to the Baltic and the Mediterranean in the West and include up to five different linguistic families: Japonic, Koreanic, Tungusic, Mongolic, and Turkic (Johanson and Robbeets, 2010: 1-2). "Transeurasian" is distinguished from the more traditional term "Altaic," which can be reserved for the linguistic grouping consisting of Tungusic, Mongolic, and Turkic languages only. In my view, the Transeurasian languages can be shown to be genealogically related, applying the classical method of historical-comparative linguistics (Robbeets, 2005, 2015).

Japanese and the other Transeurasian languages have a fair number of structural features in common, many of which are not shared with the Austrone- 


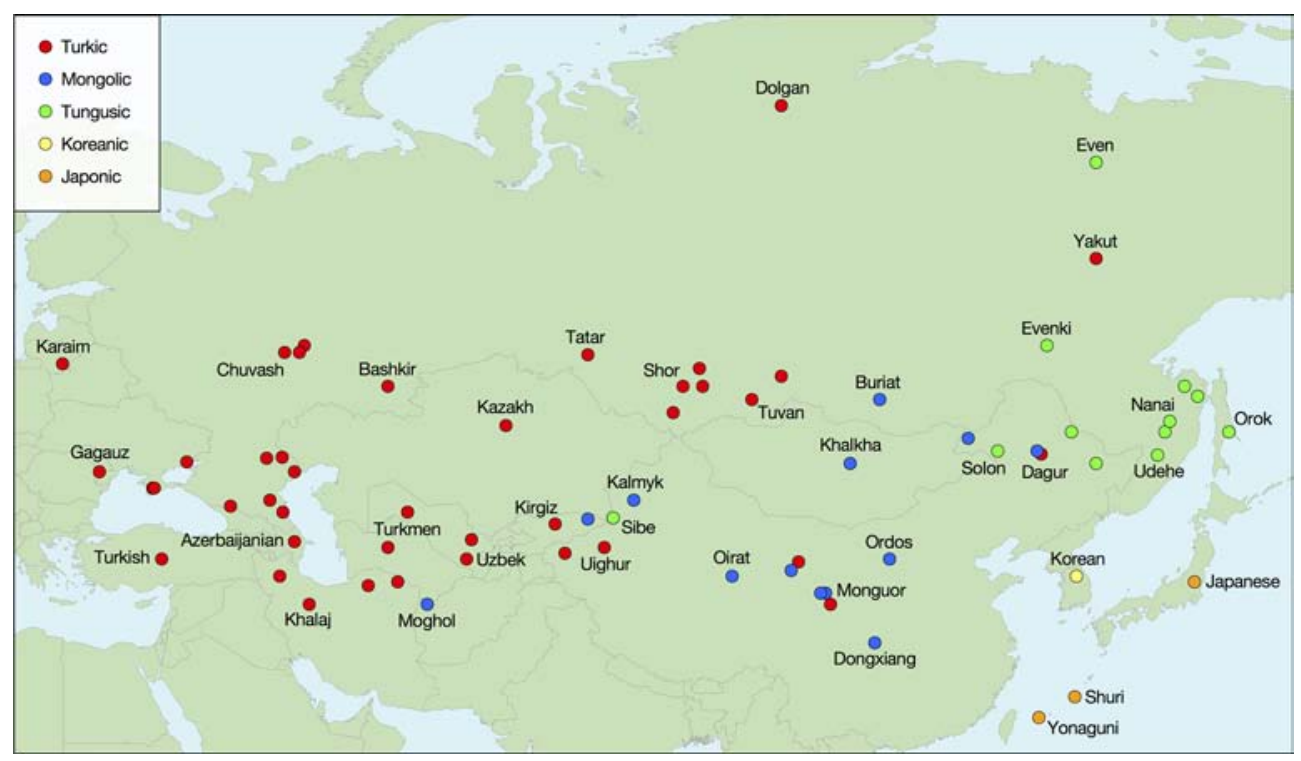

FIGURE $1 \quad$ Map of the Transeurasian languages (generated with waLs tool)

sian languages: e.g., vowel harmony, absence of initial velar nasals, absence of initial $r$-, preference for non-verbal strategies of verbal borrowing, mixed verbal and nominal encoding of property words, predominantly suffixing inflectional morphology, sov (Subject-Object-Verb) sentence order, GAN (GenitiveNoun/Adjective-Noun) phrase order, extensive use of converbs, predominant use of locative existential construction to encode predicative possession, use of the ablative case form to encode predicative comparison, etc. (see Robbeets, $2017 \mathrm{~b}$ ). Moreover, these languages can be shown to display a single set of regular correspondences for consonants and vowels, they have basic vocabulary and non-cultural vocabulary in common, count a large proportion of verbs among their cognates, share common verb morphology and spread their correspondences consistently over five branches (Robbeets, 2005, 2015). As it is generally known that languages tend to borrow nouns more easily than verbs, correspondences between verb roots are better indicators of genealogical relatedness than those between nouns or nominal adjectives (Robbeets, 2015: 163-173). As a result, some of the correlations between the Transeurasian languages are easier to explain by affiliation than by borrowing. Shared innovations in phonology, vocabulary and morphosyntax (Robbeets, 2015), as well as independent Bayesian inference (Robbeets, forthcoming), suggest the overall classification for the Transeurasian family as given in Fig. 2. 


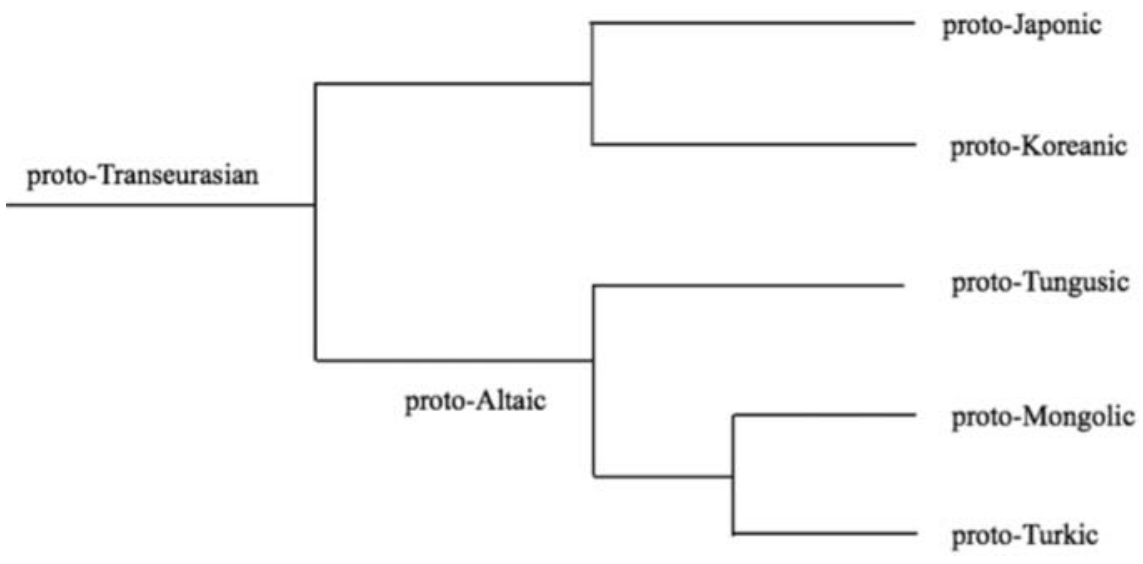

FIGURE 2 Classification of the Transeurasian languages according to Robbeets (forthcoming)

\subsection{Japanese and the Austronesian languages}

In contrast, the similarities shared between Japanese and the Austronesian languages, shown in Fig. 3, are of a different nature. Japanese has only few structural features in common with the Austronesian languages that are not shared by other Transeurasian languages as well (see Murayama, 1976, 1978; Kawamoto, 1985:105-110; Robbeets, 2017b). Examples of these properties exclusively shared between Japanese and Austronesian are a small vowel inventory, open syllable (CVCv) structure, and reduplication to express plurality.

There are at least two different sets of sound correspondences between Japanese and the Austronesian languages, which has led Kawamoto (1984) to propose that Japanese was "Austronesianized" twice. Moreover, the proposed cognates consist mainly of cultural vocabulary and nouns (Kawamoto, 1984; Benedict, 1990; Sakiyama, 1996; Kumar, 2009). There is some common morphology proposed by Kawamoto $(1979,1982)$, but it remains largely problematic. The comparisons are binary: Japanese is either compared with protoAustronesian as a whole, or else with a single subgroup or even a single language.

Table 1 contrasts the profile of the similarities for Japanese-Transeurasian with the situation for Japanese-Austronesian. The general nature of the similarities alone gives the impression that inheritance is the best explanation in the Japanese-Transeurasian case and contact is the best explanation in the Japanese-Austronesian case. 


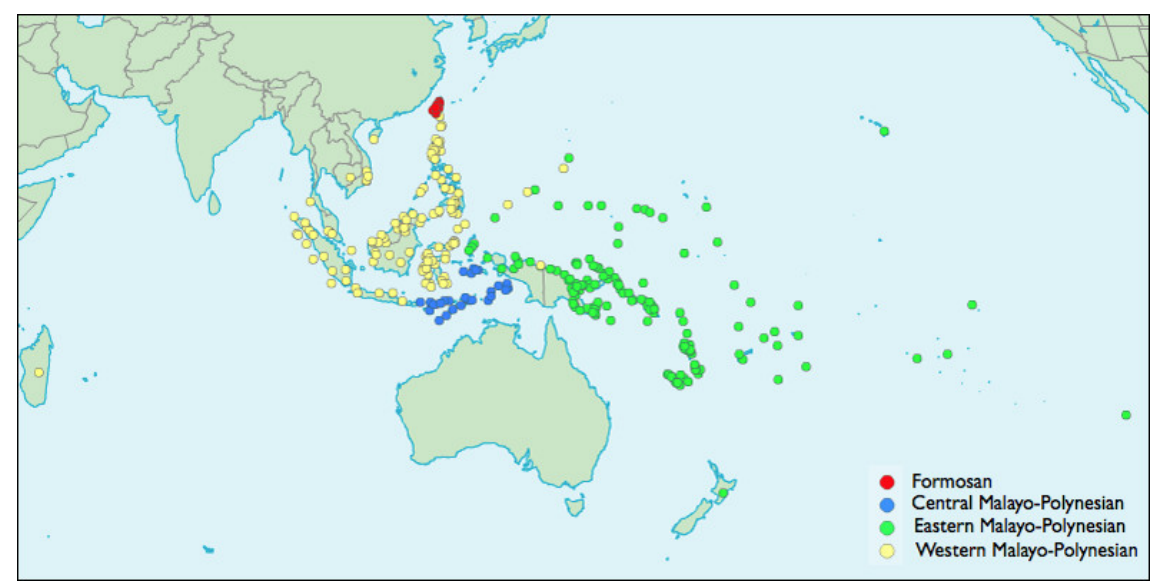

FIGURE 3 Map of the Austronesian languages (generated with WALS tool)

TABLE 1 Profile of the similarities for Japanese-Transeurasian vs. Japanese-Austronesian

Japanese-Transeurasian Japanese-Austronesian

\begin{tabular}{lll} 
Delimiting structural features & many & few \\
Sets of regular correspondences & $\mathbf{1}$ & min. 2 \\
Common vocabulary & basic/non-cultural & cultural \\
Word class of cognates & mainly verbs & mainly nouns \\
Comparative setting & five branches & binary \\
\hline
\end{tabular}

\section{$3 \quad$ Linking demographic pulses to language dispersals}

\subsection{The establishment of millet agriculture in southern Manchuria $(6500-4500$ BC)}

Chinese historical records such as the Shiji ('Records of the Grand Historian' 109-91 BC), the Sanguoji ('Records of the Three States,' 284AD) and the Houhanshu ('History of the Later Han,' 5 th century) indicate that the Turkic, Mongolic, Tungusic, Koreanic, and Japanic languages have all spread to their presentday locations from an area comprising Korea, southern Manchuria and Inner Mongolia. These sources are generally vague, and determining the location of the individual homelands on this basis alone would be speculative. However, linguistic data relating to the center of linguistic diversity, the presence of prehistorical loanwords, cultural reconstruction, and the preservation of old toponyms support the indications from historical sources. Therefore, even crit- 
ics of the affiliation of the Transeurasian languages, such as Janhunen (1996, 2009), situate the original speech communities of the individual families in this compact area.

There is a widespread misconception that subsistence patterns, such as nomadic pastoralism or hunting-gathering, have always prevailed in the Transeurasian region. Heggarty and Beresford-Jones (2014: 4), for instance, argue that in Tungusic, Mongolic and Turkic populations "agriculture never became the dominant subsistence mode ... until the modern period." However, in the area of southern Manchuria, the basis of life since the 7 th millennium BC has been millet agriculture, supplemented by fishing, hunting and gathering in the surrounding woodlands (Shelach, 200o: 367, 379-380; Hunt et al., 2008: 9, 14; Weber and Fuller, 2008: 69-90; Zhao, 2011: 301; Liu et al., 2012: 2).

The Xinglongwa culture $(6200-5400 \mathrm{BC})$, situated in the West Liao River region in Southern Manchuria (see area D on the map in Stevens and Fuller (2017: 158, Fig. 1), was among the earliest Neolithic cultures in northeast China. It preserves early evidence for the cultivation of millets, notably large quantities of broomcorn millet (Panicum miliaceum) and small amounts of foxtail millet (Setaria Italica) (Zhao, 2011: 301). The small size of the recovered grains indicates that cultivation was still in a pre-domestication stage (Liu et al., 2012: 85; Stevens and Fuller, this issue). The Xinglongwa people subsisted on a broadspectrum strategy, based on various wild and cultivated plants, including roots, beans, and nuts (Shelach, 2000; Hunt et al., 2008; Weber and Fuller, 2008; Zhao, 2011; Liu et al., 2012; Liu et al., 2016). The strengthening of monsoon around 6200 вС increased precipitation and contracted dunefields, facilitating cultivation and leading to its expansion during the ensuing Zhaobaogu (540o450о вС) and Hongshan cultures (450о-290о BC) (Jia et al., 2017). Although the Xinglongwa culture was contemporary to the Peiligang $(675 \mathrm{O}-485 \mathrm{O} \mathrm{BC})$ and Cishan (600о-500о вC) cultures south and north of the Yellow River, it was clearly culturally distinct. Whereas the Yellow River cultures were focused on agriculture, with foxtail millet as the prevailing cereal, the Xinglongwa culture, with its broad-spectrum subsistence strategy, had broomcorn millet as the most important cereal. If we associate the Xinglongwa culture with the proto-Transeurasian speech community, it would be reasonable to assume that the Zhaobaogu and Hongshan people continued the linguistic tradition, while Peiligang and Cishan people presumably spoke a different language, perhaps an ancestral form of Sino-Tibetan.

\subsection{The eastward spread of millet agriculture (4500-30оо BC)}

While cultivation is a human activity, domestication is a genetic change in a plant. This change, which manifests itself when a wild plant adapts to a cul- 
tivation regime, usually takes more than a millennium. When a plant is fully domesticated, it has become morphologically sufficiently adapted to spread to areas where the wild variety is absent, and its cultivation may create food surpluses, which in turn lead to population growth. An implication is that population expansions associated with crops are expected to take place at least a millennium after the beginning of agriculture (Stevens and Fuller, 2017). Indeed, it was not until Hongshan times (4500-290о вC) that outlying Neolithic Houwa cultures started to take shape on the Liaodong Peninsula and near Dandong on the North Korean border. Houwa people engaged in fishing and hunting as their main economy, but millet agriculture and animal husbandry were also part of their subsistence pattern (Xu, 1995: 74). Around 2800 BC, a weakening of the monsoons and a reduction in precipitation led to a major demographic decline and the collapse of the Hongshan culture (Jia et al., 2017). As the Hongshan population levels were too low to give rise to resource scarcity (Peterson and Drennan, 2011: 106; Drennan and Dai, 2017: 464), the spread of millet agriculture to the Russian Far East around 2700 в C was not driven by a population boost, but rather by climate change. Kuzmin (2013: 8) places the appearance of millet cultivation in the Primorye between 3000 вС and 2700 BC in the context of the early Zaisanovka culture (4800-1500 BC).

If we identify the early millet cultivators with the speakers of proto-Transeurasian, it is inviting to identify the first major demographic pulse associated with millet agriculture with the earliest node in the Transeurasian linguistic unity, notably the split between Altaic and proto-Japano-Koreanic. Therefore, I propose to associate proto-Japano-Koreanic with the Houwa cultures from the southern part of the Liaodong Peninsula up to the Yalu River, while linking Altaic with the Hongshan culture. I associate the separation of protoTungusic from Altaic with the adoption of millet agriculture in the Zaisanovka culture.

Archaeobotanical studies such as Crawford and Lee (2003), Miyamoto (2009) and Lee (2011) further show that Setaria and Panicum millet agriculture spread overland from the Liaodong region to the Korean Peninsula in the fourth millennium BC. Although systematic archaeobotanical study is lacking for northern Korea, the earliest appearance of domesticated foxtail and broomcorn millet in southern Korea is dated to the Middle Chulmun period, around 3500 BC (Lee, 2011: 307). Xu (1995) sees the Chulmun pottery of Korea as related to the straight-sided incised jars of Liaodong. In this context, it is conceivable that the people who introduced millet agriculture to Korea were the speakers of proto-Koreanic. Such an early date for the separation between Japanic and Koreanic is in line with the divergent nature of the Japano-Koreanic cognates in general. 


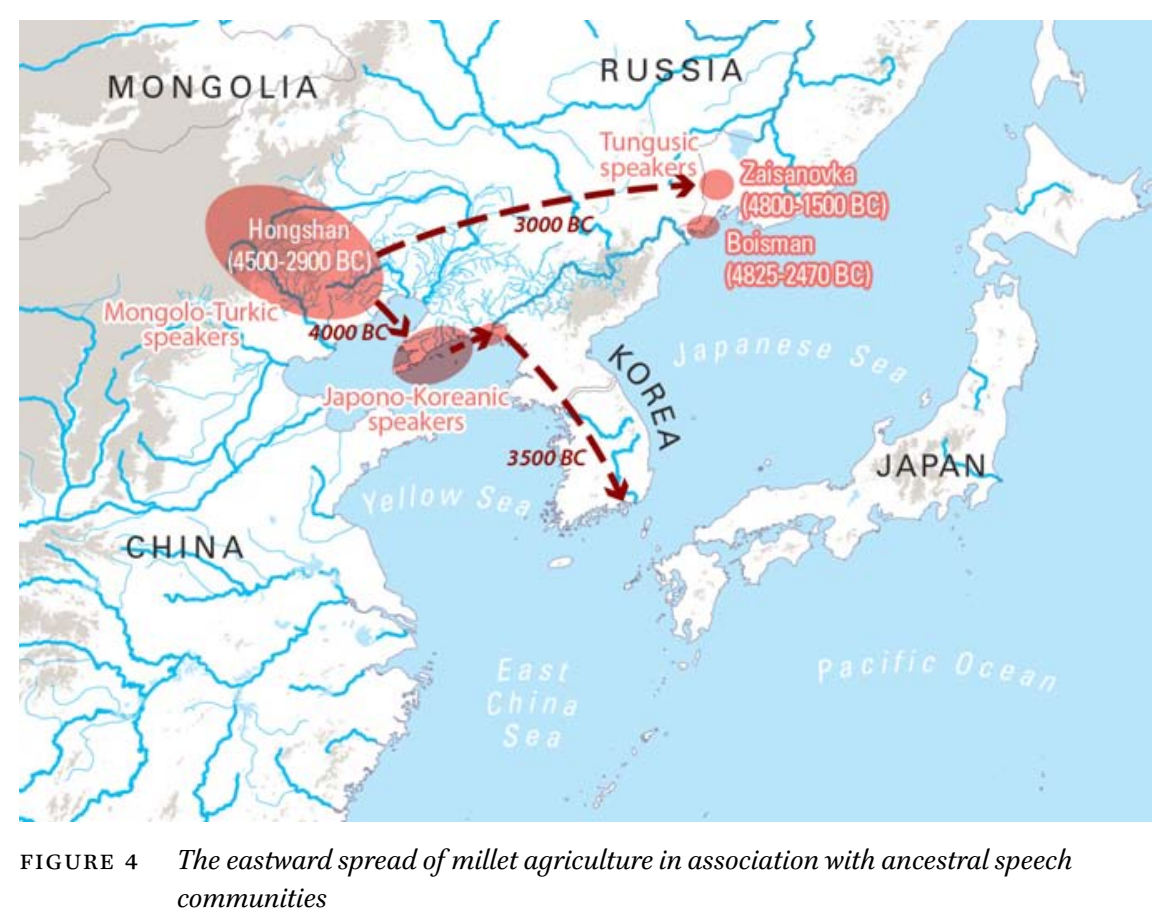

Diamond and Bellwood (2003: 599) note that language families dispersed by agriculture, such as Indo-European and Austronesian, tend to spread more rapidly along east-west axes than along north-south axes because places at the same latitude are likely to share day length and seasonality and, thus, to be suitable for growing the same crops. The spread of millet agriculture, however, pushed the Transeurasian languages mainly in an eastward direction, into the Korean Peninsula and the Russian Far East. By contrast, the westward spread of the Transeurasian languages can be associated with nomadic pastoralism. The sudden desertification of the Hunshandake Sandy Lands of Inner Mongolia in 2200 BC made the western outlier of the Hongshan culture disappear in this region (Yang et al., 2015). The people moved westwards into ecologically transitional zones and eventually shifted from semi-mobile millet farming to pastoralism in the eastern Eurasian steppes. Equestrian pastoralism developed in the eastern steppes between 1200 and 7оо вС (Taylor et al., 2017). The Xiongnu, a mixture of ethnic groups, some of which have been identified as ancestral speakers of the Oghuric branch of Turkic, ruled as nomads in that area between 209 BC and 155AD. Therefore, the desertification of Hunshandake in 2200 BC may be associated with the separation and westward spread of the Turkic speakers. Later, in historical times, they accelerated their westward spread 
from present-day Mongolia toward central Asia due to horseback riding, replacing Indo-Iranian languages on the Asian steppes and ultimately arriving in Anatolia in the 11th century AD. A southward expansion of Transeurasian languages was probably limited by demographic pressure from other farming populations in the south, presumably speakers of Sinitic and para-Austronesian languages. Migration to the north was prevented by climatological conditions, as rainfall and the number of growing days were inadequate for millet farming. Therefore, the main outlet for the agriculture-driven dispersal of Transeurasian languages was in an eastward direction.

\subsection{The integration of rice and millet agriculture after 3 ооо вс}

A second major demographic pulse in Northern China is associated with the integration of rice into the millet agricultural assemblage and a subsequent population spread. The Hongshan and Houwa cultures in southern Manchuria were contemporary with the Yangshao (5000-280о BC) and Dawenkou (410026 оо вС) cultures of the Yellow River Basin. However, as indicated above, whereas the former were similar to each other, they were quite different from the Yellow River cultures. As far as agriculture is concerned, broomcorn millet was prevalent in Hongshan, while foxtail millet dominated in the early stages of the Yellow River cultures. In addition, the Hongshan culture did not rely on rice agriculture, whereas rice was added to the agricultural assemblage around 4000 BC in the Yangshao culture and around 3000 вС in the Dawenkou culture (Fuller and Stevens, this issue). Sagart et al. (this issue) propose that millets and rice were already cultivated together in the Peiligang $\left(675^{\circ}-485\right.$ о вС) and Houli (6500-500о BC) cultures in Henan and Shandong, but Fuller and Stevens (this issue) stress that there is no conclusive evidence to regard this early rice as domesticated, and that it played no role in the subsequent spread of rice agriculture. Given the expansive nature of the Yangshao culture, the possibility cannot be excluded that it transmitted rice cultivation to the Dawenkou culture, although there is no concrete archaeological evidence for favoring a western route over a southern coastal route for the importation of rice agriculture.

Whereas the Yangshao culture is generally associated with the homeland of Sino-Tibetan, some scholars such as Sagart (2008, 2011: 27; Sagart et al., this issue), Blench (2008) and Van Driem (1998: 93-94) suggest that the Dawenkou culture should be linked to a para-Austronesian presence.

Indications for an Austronesian connection to the Dawenkou culture come from various kinds of evidence: the use of pottery with supporting legs, house structure, myths on the sun, burial rituals such as the use of slab tombs (Zhang, 2009), cranial measurements ( $\mathrm{Wu}$ and Olsen, 2009), and the shared ritual of 
tooth ablation, notably the extraction of healthy upper lateral incisors as a puberty rite (Han and Nakahasi, 1996: 47-48; Pietrusewsky et al., 2014). Moreover, it is more likely that Austronesian agriculture spread to Taiwan from Shandong than from the Lower Yangtze River, as previously suggested by Blust (1996) and Bellwood (2005), because millets and rice arrived as an integrated assemblage in Taiwan around 3000-2400 BC, while Lower Yangtze agriculture focused exclusively on rice until 200о BC (Weber and Fuller, 2008: 80; Stevens and Fuller, 2017). The excavation of marine shell midden sites (Yuan et al., 2002) has further revealed that the Dawenkou was a maritime-focused culture, in contrast to the Lower Yangtze culture, which lacked marine sources. The extent of the correlations between the coastal cultures of Shandong and Taiwan remains to be investigated, but it is probable that the millet-rice agricultural assemblage was transmitted around $3000 \mathrm{BC}$ from Shandong to Taiwan over a maritime route. In addition, Ko et al. (2014: 430) find evidence from mitochondrial DNA that supports a separation between Austronesian and SinoTibetan populations around 8000-6оoо BC, well before Austronesian populations started to expand into Taiwan.

The Shandong-Liaodong coastal interaction sphere is the obvious candidate for the setting of early contacts between the (presumably para-Austronesian) Dawenkou of Shandong, the (presumably Sinitic) Yangshao of the Lower Yellow River, and the (presumably Japanic) Houwa cultures of the Liaodong Peninsula. Judging from the archaeological data $(\mathrm{Xu}, 1995: 78-79,85)$, the people from the Shandong and Liaodong Peninsulas had economic contacts very early, beginning in the fifth millennium вс. In terms of influence, the Dawenkou and Longshan cultures of Shandong had more impact upon the Houwa culture in Liaodong than the other way around, which is witnessed, for example, by finds of typical Dawenkou tripod footed basins, jars and boat-shaped vessels on Liaodong.

Archaeobotanical studies such as Miyamoto (2009) and Ahn (2010) show that wet-rice cultivation came to Korea in the late second millennium BC (1300-100о BC) via the Shandong and Liaodong Peninsulas. This marks the beginning of the Mumun culture (1300 BC-OAD) in Korea. Rice agriculture was more popular in the central and southwestern regions of Korea than in the southeast, where dry-field crops including millet and soybean remained important. Simultaneously, the custom of ritual tooth ablation spread over to the Liaodong Peninsula and then to the southern end of the Korean Peninsula, but relatively few skulls with ritual tooth ablation have been unearthed from these regions (Han and Nakahasi, 1996: 57). In addition to their customs and subsistence mode, the wet-rice cultivators may have brought the Japanic language to the Korean Peninsula. 


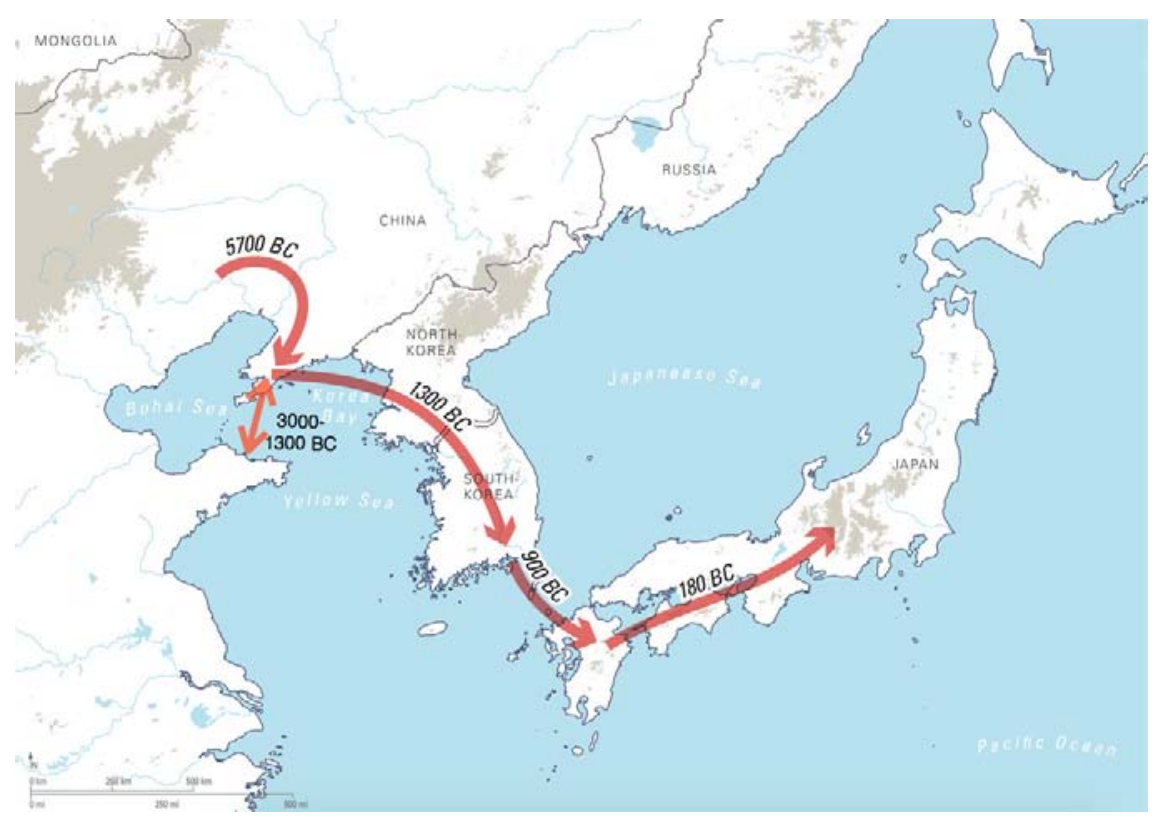

FIGURE 5 The spread of agriculture and language to Japan

The final spread of millets and rice into Japan is dated to the beginning of the first millennium BC, marking the beginning of the Yayoi period (1000 BC$300 A D)$. It is associated with an influx of farmers from the Korean Peninsula (Harunari, 1990; Nelson, 1993; Hudson, 1999; Crawford and Shen, 1998; Crawford and Lee, 2003; Harunari and Imamura, 2004; Barnes, 2015), who probably brought the Japonic language to Japan. Apart from rice, millets and various crops, Northeast Asian influences include pottery, stone and wooden agricultural tools, domesticated pigs, ditched settlements and megalith burials. It is clear that agriculture arrived in Japan as a "package" of Northeast Asian culture, even if this package had a southern, Austronesian-like touch. Wet-rice agriculture was ultimately derived from the south, and certain elements of Yayoi culture such as ritual tooth ablation (Han and Nakahasi, 1996: 58, Brace and Nagai, 1982: 405), tattooing with dragon figures to ward off monstrous fishes (Pauly, 1980: 82; Sasaki, 1991: 26-27; Solheim, 1993: 2; Bellwood, 1997: 108, 135; Oppenheimer, 1998: 77; Palmer, 2007: 51), and granaries with raised floors, curved roof-lines and gable horns (Pauly, 1980: 84; Waterson, 1997: 17; Arbi et al., 2015) indicate an Austronesian connection. As a result, the most parsimonious hypothesis, in my view, is the early, continental insertion of Austronesian elements into an essentially North East Asian cultural package, as illustrated in Fig. 5. 
Another way to integrate archaeological and linguistic evidence is to correlate reconstructed subsistence words with prehistorical locations and archaeological cultures. As illustrated below, common words indicative of cultivation and weaving can be reconstructed back to proto-Transeurasian, while shared maritime vocabulary and rice terminology are lacking (see also Robbeets, 2017c, for the reconstruction of additional vocabulary that associates proto-Transeurasian with broad-spectrum subsistence, including consumable plants such as nuts and roots and subsistence activities such as "grinding" and "kneading," and indirect lexical evidence for pottery production). This observation supports the identification of the Xinglongwa culture with proto-Transeurasian. By contrast, Japanese and Korean share coastal subsistence terms, but they lack common rice vocabulary, an observation which supports the association of proto-Japano-Koreanic with the Neolithic Houwa cultures on the Liaodong Peninsula. Finally, the observation that some Japanic rice terms seem to derive from Austronesian supports the addition of rice to the earlier millet agricultural assemblage under influence of the-presumably para-AustronesianDawenkou culture.

\subsection{Cultivation in Transeurasian}

First, the comparison of lexical items relating to millet cultivation can shed some light on the hypothetical scenario. A possible candidate for cognacy is a term that combines the meaning 'seed' and 'millet,' given in (1). The etymology briefly proposed in Robbeets (2017a) is explained in more detail here.

(1) pTEA *pusu- 'to sprinkle with the hands' *pisi- 'sprinkle with the hands, sow' $\rightarrow$ *pisi 'what is sown'

$>$ *pisi 'seed, seedling' (pTEA *-i deverbal noun suffix)

$\rightarrow$ * pisi-ke 'major crop' (pTEA *-kA plant suffix)

a. Mongolic: pMo *hüsü- *hisü-/hesü- 'to sprinkle, throw out, jump around' $\rightarrow$ *hisi/*hesi 'origin or base of a plant, shoot' (pMo *-i deverbal noun suffix)

pMo *hüsü-r- *hesü-r-/*hisü-r- 'to sprinkle, scatter; jump around' (pMo*-r-intensive)

Middle Mongolian üsür- ' 1 to spout, squirt out (of water); 2 to jump, leap (intr.),' Written Mongolian üsür- '1, 2,' Khalkha üsre- 'to squirt; to jump, leap, skip,' Buriat hür- 'to jump, leap,' Ordos üsür- 'to jump, leap,' 
Kalmuck ösr- 'to sprinkle (water), throw out sparks (of fire); jump or hop (of insects), to fly in the air' (Ramstedt, 1935: 301), Dagur xesere'to jump' (Martin, 1961: 161), xəsur-, xesurz- 'to sprinkle,' Eastern Yugur husur- 'to jump,' Dongxian usuru- 'to flow,' Monguor fizuru-, fuzuru- 'to sprinkle, pour, cast (metal),' Moghol üsürü- 'to jump, leap' (Ramstedt, 1906)

pMo *hisi/*hesi 'origin or base of a plant'

Middle Mongolian nisi, hesi, Written Mongolian isi esi ' 1 foundation, basis, origin, source; 2 a stalk of grain, trunk of a tree, stem of a plant, shoot; 3 handle, grip,' Khalkha iš eš '1 source, basis; 2 stem, stalk, trunk, underground stem; 3 handle, shaft' (Bawden, 1997), Buriat eše '1, 2, 3,' Kalmuck iš ' 1 beginning, source; 2 stalk (of plant), stem (of tree), 3 handle, grip' (Ramstedt, 1935: 210), Ordos eši iši '1, 2, 3,' Baoan jeśi, hesï 'handle, grip' (Nugteren, 2011: 354), Dagur xeš, xeši, heši 'handle, grip, knob' (Martin, 1961: 161), Eastern Yugur ša 'handle, stem,' Kangjia heši 'handle, grip' (Nugteren, 2011: 354)

b. Tungusic: pTg "pusu- 'to spread' "pisi- 'to sprinkle with the hands' / "pise- 'to spread out'

$\rightarrow$ * pise 'offspring' (through pTg * $i$ deverbal noun suffix?)

$\rightarrow$ * pisi-ke 'broomcorn millet' (pTg * ${ }^{*} k A$ plant suffix)

pTg "pusu- 'to sprinkle, to scatter' "pisi- 'to sprinkle with the hands' / "pise- 'to extend out'

Manchu fusu- 'to sprinkle (water), spew, spirt, squirt,' fuse- 'to propagate, to reproduce, to breed,' fisi- ' 1 to sprinkle with the hands, 2 to shake, to toss (one's sleeves),' fise- ' 1 to project, to jut out, 2 to fork, to branch' (Norman, 2013), Sibe fusu- 'to sprinkle,' Even hus- 'to sprinkle (with water), splash, sputter, disperse,' Negidal xusi- 'to sprinkle,' Olcha pisuri- 'to sprinkle,' Orok pisitči-, possoli- 'to sprinkle,' Nanai pisi-, fisi-, fuksu- 'to sprinkle' (Cincius, 1975-1977: 39, 42, 355)

pTg *pise 'offspring'

Manchu fisen 'relation, offspring, progeny' (Norman, 2013), Okhotka dialect of Even hesen 'seed, offspring, kin' (Starostin et al., 2003)

pTg *pisi-ke 'broomcorn millet'

Manchu fisihe $\sim$ fisike 'glutinous millet, broomcorn millet (Panicum miliaceum),' fisitun 'a ritual vessel for offering millet; bowl for grinding 
millet, carved out from a piece of wood' (< fisi + tetun 'utensil') (Norman, 2013), Olcha pikse 'millet,' Nanai pikse 'millet,' Kur-Urmi dialect fisxe 'millet'

c. Koreanic: $\mathrm{pK}{ }^{*} p u s u$ - 'sprinkle, scatter, wash, smash' $\sim \mathrm{pK}$ "pisi- 'sprinkle, scatter, sow' $\rightarrow$ " $p i s i$ ' what is sown' $\left(\mathrm{pK}^{*}-i\right.$ deverbal noun suffix $)>\mathrm{pK}{ }^{*} p s i$ 'seed, lineage'

$\rightarrow$ pisi-k 'major crop' (pK *-kplant suffix) > "pski- > "phi 'barnyard millet'

pK "pusu- 'to sprinkle, scatter, sow' "pisi- 'to sprinkle, scatter, sow' $\mathrm{K} p u: s-$ ' 1 to pour, 2 to sow (tr.),' K pu:s- $\sim \mathrm{K}$ puswu- 'to smash, scatter, break,' мк poso- 'break, shatter,' к pusi- 'to wash, clean, rinse,' мк puswoy- 'to wash, clean, rinse (tr.),' к pusule tuli- 'to smash, to shatter into splinters (tr.),' к pusule ci- 'to crumble (intr.)' (к -le tuli-/-le cicausativity polarizer $<\mathrm{pK}^{*}-(\Lambda / \dot{t}) l$ - anticausative $), \mathrm{K}$ pusul pusul $\sim$ posul posul 'gently raining,' к pusik ha- 'to plant, extend' (Martin et al., 1967) (MK - $i$ - transitivizer < $\mathrm{pK}^{*}-i$ - causative); K ppu:li- ' 1 to sprinkle, rain slightly (intr.); 2 to sprinkle, shower, water (tr.); 3 to scatter, sow,' к ppuli 'a root (of a plant),' M K spu-li- 'to sprinkle' ( $\mathrm{MK}-(u) l i$ - transitivizer $<\mathrm{pK}$ *-(u)l-anticausative $+{ }^{*}-i$ - causative), MK spih- 'to sprinkle; slander,' $\mathrm{K}$ p:al- 'to wash, launder, wash out (tr.),' $\mathrm{MK} \cdot$ spol- 'to wash (tr.)' ( $\mathrm{pK}$ *$(\Lambda / \dot{t}) l$ - pluractional), MK $\cdot s p u m$ - 'sprinkle, spout, spurt' ( $\mathrm{pK}^{*}{ }^{*}-m \dot{t}-\sim m \boldsymbol{c}^{-}$ inclinational)

pK *psi 'seed, lineage'

MK .psi, к ssi '1 seed, kernel, 2 lineage, descent, breed,' к pye-pssi 'rice seed'

pK *phi 'barnyard millet'

MK .phi, K phi '(Japanese) barnyard millet (Echinochloa esculenta)'

d. Japonic: pJ "piyai "piyia "piye 'barnyard millet' J hie, oJ pi $i_{1}$ ye '(Japanese) barnyard millet (Echinochloa esculenta)'

In the Mongolic verbs, the semantic shift from 'to sprinkle' to 'to jump' can be explained by observing the semantics of the Kalmuck verb ösr- 'to sprinkle (water), throw out sparks (of fire); jump or hop (of insects), to fly in the air,' in which the common denominator is 'to scatter of a set of small items.' The deverbal noun of this verb has the primary meaning 'what is scattered, sown.' The semantic development in the nouns extends from 'what is sown' from 
'origin or base of a plant' to any 'origin, base' and specializes from 'origin, base of a plant' to 'stem of tree' to 'handle, grip.'

Given the lexicalization of a deverbal intensive suffix pMo * $r$ - in a number of Mongolic verb stems (e.g., ayimu- 'to become confused, mixed up, go astray, be unintelligible (intr.)' $\rightarrow$ ayimur- 'to change for the worse, indulge in lustful pursuits, be seduced, be heavily confused (intr.),' ciki- 'to jam, stuff, press, push; stuff oneself, overeat (tr./intr.)' $\rightarrow$ cikir- 'to be unable to pass through or fit in, get stuck,' sibqa- 'to scrape out, scoop out, empty out (tr.)' $\rightarrow$ sibqar- 'to squeeze out, pour out to the last drop, empty out (tr.)' and jaki- 'to give instructions, to entrust, to give an order for, to ask to run an errand (tr.)' $\rightarrow$ jakir- 'to rule, govern, direct, subordinate, subject (tr.)'), we can reconstruct the bare root pMo *hüsü- *hisü-/hesü- 'to sprinkle, throw out, jump around.' The noun *hisi/*hesi 'origin or base of a plant, shoot' can be derived from the root *hesü$/$ 'hisü- by suffixation of the deverbal noun suffix pMo *-i, e.g., in WMo. sönü- 'to be extinguished, go out (of fire), cease to be' $\rightarrow$ söni 'night, at night' (Robbeets, 2015: 462-463).

Monguor fizuru- 'to sprinkle, pour, cast (metal)' preserves a reflex of the high front vowel in pMo *hisür-. The reconstruction of initial $\mathrm{pMo}^{*} h$ - is supported by the Buriat, Dagur, Eastern and Monguor verbs and by the Dagur, Kangjia and Baoan nouns. The antiquity of initial ${ }^{*} h$ - and its origin in pre-pMo ${ }^{*} p$-is further supported by the borrowing of the term as pTg "pesin 'handle' (in Manchu fesin, Sibe fesan, Evenki hesin, Even hesïn, Negidal xesin, Olcha pesi $(n)$, Orok pesi $(n)$, Nanai pesĩ, Oroch $x e s i(n)$ and Udehe $x e h i)$. The observation that the Tungusic meaning is limited to 'handle,' which is secondary in Mongolic, is indicative of borrowing.

The Tungusic verbs reflect the meaning 'to sprinkle, to scatter.' The meaning 'to sow' is not attested, but the polysemy is observed in other Tungusic verbs, e.g., Sibe swata- 'to sprinkle, sow' (Kim et al., 2008: 150). The noun pTg "pisi 'what is scattered, what is sown' can be derived from the verb "pisi-'to sprinkle with the hands' by suffixation of the deverbal noun suffix pTg ${ }^{*} i$, reflected, for instance, in Even tet- 'to dress oneself' $\rightarrow$ teti: 'garment, uniform' and Evk. usi:- 'to bind' $\rightarrow$ usi: 'rope, belt' (Robbeets, 2015:461-462). Although I cannot explain the final vowel in pTg "pise 'offspring,' I think it concerns a nominalization of the same verb. The semantic development probably went over 'seed' in a similar way as the polysemy in K ssi ' 1 seed, 2 lineage, descent,' as discussed below. Starostin et al. (2003) gloss the word hesen from the Okhotka dialect of Even as 'seed, offspring, kin,' but I have not been able to trace that form back. ${ }^{2}$ Since the

2 Note, however, the noun pTg *ise $\sim$ *use 'seed,' which reflects the same vowel alternation and 
final nasal in Okhotka Even hesen and Manchu fisen is instable and frequently drops when inflectional suffixes are attached, I do not consider it part of the root.

The morphological complexity of Manchu fisitun 'millet bowl' suggests that pTg "pisi-ke 'broomcorn millet' includes a petrified derivational suffix of the shape pTg ${ }^{*}-k A,{ }^{3}$ found in the names of animals and plants, e.g., in pTg ${ }^{*}$ tasaka 'tiger' (e.g., Ma. tasxa, Jurchen tasxa, Solon tasax), pTg *kumi-ke 'louse' (e.g., Evk./Even/Neg. kumke and Evk. kumikēn 'insect,' Na. kuyke, Ud. kumuge, Solon xujkē and xumixxe 'ant'), pTg *inū-ke 'dog, wolf' (e.g., Evk. ńékē 'sable,' Even $\eta \overline{o ̈ k e ~ ' m a l e ~(o f ~ d o g, ~ w o l f, ~ f o x), ' ~ S i b e ~ j u x ə ~ ' w o l f, ' ~ M a . ~ n ́ o x e ~ ' w o l f ', ~ n u x e r e ~ ' p u p p y ') ~}$ pTg *eb-ke 'heather' (e.g., Evk. ebkemkirē, Neg. epkexin, Orok/Oroch ewxexi, Na. opokta 'hawthorn') and pTg *bolo-ka 'spiraea' (Evk. boloko, Neg. boloxokto, Na. boloqto, Ud. bolokto).

In Korean we find two sets of reflexes: one set reflecting * $u$ - vocalism and, therefore, resisting vowel loss, and another set reflecting * $i$ - vocalism and, therefore, subject to vowel loss and subsequent initial $s p$ - clustering in Middle Korean and $p p$ - reinforcement in contemporary Korean. In line with Ramsey (1993: 438; 1997), I assume that MK verb stems with complex initials that are tonic and monosyllabic and have minimal vowels ( $\mathrm{MK} o, u, i$ ) are created through the loss of a first-syllable vowel. This internal analysis justifies the reconstruction of the first high front vowel in "pisi- 'to sprinkle, scatter, sow' on the basis of M K spu-li- 'to sprinkle,' MK spih- 'to sprinkle; slander,' MK ·spol'to wash (tr.)' and $\mathrm{MK} \cdot$ spum- 'sprinkle, spout, spurt' (the dot preceding a syllable indicates that the stem is tonic).

Korean has a number of defective converbs, recognizable by the converb ending $-e /-a$ and preceded by an element $-(u) l-$. They occur with the auxiliary verbs ci- 'to become,' which polarizes their intransitivity, and ttuli- 'to make,' which makes them transitive: e.g., K wuk- 'to turn' $\rightarrow$ wukule ci- 'to curl up (intr.),' wukule ttuli- 'to make a dent in (tr.).' The transitive analytic construction in -(u)l-e ttuli- replaces an older and almost obsolete suffix in - $(u) l i$ - that likewise adds transitive meaning and goes back to a synthetic form $-l-i$, where $i$-reflects the causative $\mathrm{pK}{ }^{*}-i$-, e.g., $\mathrm{K}$ wuk- 'to turn' $\rightarrow$ wukuli- 'to crouch, crush (tr.)' (Robbeets, 2015: 310-311). These suffixes take part in the derivation of $\mathrm{k}$ pusule tuli- 'to shatter into splinters (tr.),' к pusule ci- 'to crumble (intr.)' and к ppu:li-,

may be due to loss of the initial labial stop. The form can be reconstructed on the basis of Manchu use, Jurchen use, Olcha use, Nanai use and Oroch usi 'seed.' The original front vowel is preserved in derived verbs such as Evenki isew-, Even isu-, Negidal isew- and Udehe jehu'to grow.'

3 The capital A in the suffix pTg ${ }^{*}-k A$ represents vowel harmony. 
MK spu-li- ' 1 to sprinkle; 2 to scatter; 3 sow' from pK *pusu- 'to sprinkle, scatter, sow.' Korean has further lexicalized two adverbial suffixes $\mathrm{pK}^{*}-l$ and $\mathrm{pK}^{*}-k$, for instance, in the derivation of santul 'light,' santul santul 'in cool ripples' and santuk 'with a sudden chill' from pK *santi- 'to be light, fresh, cool' (Robbeets, 2015:469-470). They participate in the derivation of K pusul pusul posul posul 'gently raining' and $\mathrm{k}$ pusik ha- 'to plant, extend' from pK "pusu- 'to sprinkle, scatter, sow.' Moreover, the pluractional marker $\mathrm{pK}^{*}-(\Lambda / t) l-$, indicating that an action is carried out multiple times, by multiple agents or on multiple objects (e.g., in $\mathrm{MK} \cdot \operatorname{spo}(l)$ - 'to sip, inhale,' $\mathrm{MK} \cdot a w o(l)$ - 'to join together' and $\mathrm{MK} \cdot s k o(l)-$ 'to spread out, pave with (tr.)' - vs. MK ·ski- 'cloud up'), derives MK ·spol- 'to wash (tr.)' from $\mathrm{pK}$ * pisi- 'to sprinkle, scatter, sow.' Finally, the inclinational marker $\mathrm{pK}$ *-mit/ -, e.g., K mek-, MK mek- 'to eat; harbor (a feeling) (tr.)' $\rightarrow$ K mekum-, MK me.kwum- 'to hold in the mouth; to swallow, gulp down; harbor (a feeling/idea) (tr.)' (Robbeets, 2015: 250-251) explains the formation of MK ·spum- 'sprinkle, spout, spurt' from this root.

In Korean and Middle Korean, we find the causative suffixes $\mathrm{K}-k i-,-h i-,-i-$, $\mathrm{MK}-\cdot \mathrm{Ki}-,-\cdot G i-,-\cdot h i-,-\cdot i-$ that can be derived through velar lenition as allomorphs from $\mathrm{pK}^{*}$-ki-, e.g., $\mathrm{MK}$ cec- 'to be wet' $\rightarrow$ ce.ci- 'to moisten (tr.)' and $\mathrm{MK}$ nep- 'to be wide' $\rightarrow$ MK ne.phi- 'to widen (tr.)' (Robbeets, 2015: 320-321). These suffixes take part in the derivation of $\mathrm{MK}$ puswoy- 'to wash, clean, rinse (tr.)' from $\mathrm{pK}$ "pusu- 'to sprinkle, scatter, sow' and of MK spih- 'to sprinkle' from pK "pisi- 'to sprinkle, scatter, sow.'

In Middle Korean, we find MK .psi 'seed' in addition to MK . phi 'barnyard millet.' As hinted above, tonic, monosyllabic, open stems with aspirate initials followed by a minimal vowel $(u, o, i)$ can be derived from an originally disyllabic root with an initial minimal vowel, i.e., in this case, $\mathrm{pK}$ * pisi 'what is sown, seed'. I assume that the addition of a velar plant suffix caused the aspiration in the term for 'barnyard millet,' i.e. pK "pisi-k (what.is.sown-PLANT) > "pski > "phi.

I do not exclude the possibility that the Japanese verb hisigu 'crush, smash' (< " pisi-nku-) and the verbal adjective hisasii 'long, long-continued' (< "pisa$s i-)$ are ultimately related to this etymon. This remains speculative, but the coincidence in meaning between $\mathrm{J}$ hie, oJ pi,ye and the Korean form can hardly be coincidental. Since the vowel type (1 or 2$)^{4}$ is not distinguished following glides in Old Japanese, there is no conclusive evidence for the reconstruction of the final vowel in oJ pi $i_{1} y e$ 'barnyard millet.' The possibilities are "piyai

4 Note that Old Japanese distinguished between two values for later $e, i, o$ in certain syllables, which are indexed with subscripts $i_{1}$ vs. $i_{2}, e_{1}$ vs. $e_{2}$ and $o_{1}$ vs. $o_{2}$. Japanese verbs and verbal adjectives can be distinguished according to two prosodic classes, called A and B, corresponding to a high and low initial tone, respectively. Prosodic classes for nouns are more complex 
"piyia "piye. The correspondence between the palatal glide $-y$-in Japanese and the $-s$ - in Tungusic and Korean is irregular, but a few etymological sets within Japanese seem to involve internal alternation between $s \sim t$ (e.g., hisasii 'long, long-continued' hita- 'straight, unceasing,' hutagu 'close, stop up' husagu 'close, stop up,' oJ $s i \sim t i$ 'wind, direction' etc.) and between $t \sim y$ (e.g., itamu 'hurt' yamu 'ail,', taku yaku 'burn (tr.),' tatu tayasu 'cut off (tr.),' etc.) Thus we cannot exclude that pJ "piyai "piyia *piye ultimately derives from *pisai $\sim$ "pisia "pise.

The convincing power of this etymology follows from the shared peculiarities of the Mongolic, Tungusic and Koreanic reconstructions. First, there is a shared alternation between the vowels in the verb bases that corresponds regularly and reconstructs back to a ${ }^{*}-u^{-} \sim^{*}-i$ - vowel alternation in protoTranseurasian. Second, the peculiar polysemy of 'to sprinkle' and 'to sow' is shared by the Mongolic, Tungusic and Koreanic proto-forms. This polysemy is recurrent throughout the Transeurasian languages, including verb roots that are not cognate to the root under discussion, such as Japanese maku 'to sprinkle, scatter, strew, sow (seed), hodokosu 'sprinkle, scatter, sow; give, perform, apply,' Sibe swata- 'to sprinkle, sow,' Turkish sač- 'to sprinkle, scatter, sow (seed),' $e k$ - 'to sprinkle, scatter, drop, throw about, sow (seed),' etc. The derivation of the word for a major field crop by way of a nominalization of the verb 'to sow,' as proposed for the Tungusic term for 'broomcorn millet' and the Korean term for 'barnyard millet,' is reminiscent of the development of proto-Turkic *tari- 'to cultivate ground' into the deverbal noun Uzbek tariq 'broomcorn millet' (Savelyev, 2017).

Third, the nominal derivations with a corresponding deverbal noun suffix are shared, as well as the suffixation of a velar plant suffix, in Tungusic and Koreanic. The formally and functionally corresponding derivations suggest that the suffixes were productive at their most recent common ancestral stage and probably on their way to lexicalization in the individual protolanguages. Due to these shared pecularities at the phonological, semantic and phonological level, this etymology provides a strong argument for cognacy, while it is unlikely to be the result of borrowing.

and marked with a number notation. Adequate information about these prosodic patterns is only available from the Middle Japanese stage onwards.

For Middle Korean the Yale romanization is modified to allow for the representation of unrounded vowels $[\Lambda]$ and $[\mathrm{i}]$ by $o$ and $u$. In proto-Korean these vowels are reconstructed as ${ }^{*} \Lambda$ and ${ }^{*}$. The dots in the Middle Korean words represent the distinctive pitch of the following syllable: one dot for high, two dots for rising, and unmarked syllables are treated as low. 
From the perspective of cultural reconstruction, it is informative that the semantic development from 'sprinkle' to 'sow' and the morphological derivation from 'sow' to 'what is sown' to 'seed' took place at the stage of protoTranseurasian. This allows us to infer that sowing, and thus plant cultivation, was adopted and gradually developed by the speakers of proto-Transeurasian. We find a very similar situation in Indo-European, where the derivation from pIE * $s e H_{1}$ - 'to sow (seed)' to * $s e ́ H_{1} m_{0}$ 'seed' can be reconstructed to the level of the ancestral language because both the verb roots and derived nouns are regularly corresponding and derived by way of a common deverbal noun suffix: e.g., in Germanic, Old English sāwan 'to sow,' Gothic saian 'to sow' and Old High German sāmo 'seed'; in Romance, Latin serō 'I sow' and sēmen 'seed'; in Slavic Old Church Slavonic sějg 'to sow' and sěmę 'seeds'; in Baltic, Old Prussian situn 'to sow' and simen 'seed,' Lithuanian sèti 'to sow' and sekla 'seed,' semenis 'linseed'; in Celtic, Old Irish sĭl, Welsh hil 'seed'; in Sanskrit sî́ra- 'plow'; and in Hitite ishūwāi '(he) sows.'

The common derivation from the verb 'to sow' as well as the shared combination of the two meanings 'seed, millet' in Tungusic and Korean seems to imply that some kind of millet was targeted for its seeds and existed as a major crop in the culture in which the ancestral language was spoken. Although there is no evidence for full domestication of barnyard grass in northeast China in the Neolithic period, it is known that it formed part of the diet. The narrow range of wild grasses recovered in Neolithic sites in dry farming contexts in northeast China indicates that people were selecting the wild ancestor of Japanese barnyard millet as opposed to other grasses (Bestel et al., 2014: 264). Seeds of barnyard millet were also retrieved from early agricultural sites of the Zaisanovka culture in the Russian Far East (Kuzmin, 2013).

The next candidate for cognacy, discussed in (2), is a term with the meaning 'field (for cultivation),' with reflexes in Turkic, Koreanic and Japonic.

$$
\text { pTEA *pata 'field for cultivation' }
$$

a. Turkic: pTk *(p)atï * $(p)$ ata 'field irrigated for cultivation' (pTk *-z collective suffix, pTk *-(A)g place suffix?) от (Karakhanid) atiz 'any strip of land between two dikes,' MTk. atïzla'to create an irrigation canal in a field,' Uighur etiz 'watered field, boundary,' Turkmen atiz 'watered field, boundary,' Shor adis 'a measure for fields, $1 / 18$ dessiatin (= ca. 607 square meters), Kirgiz adir 'hilly terrain,' Kazakh atiz 'a plot of land, watered by irrigation canals and properly limited'; MTk. atov '1 island,' Turkish ada '1,' Tatatar ataw '1,' Turkmen a:da '1', Chuvash odă ' 1 ' 
b. Koreanic: $\mathrm{pK}$ *patn '(dry) field' ( $\mathrm{pK}^{*}-(\dot{t} / \AA) k$ place suffix) $\mathrm{K}$ path, $\mathrm{MK}$ path '(dry) field, farm, patch, garden, position on a game board'

c. Japonic: pJ "pata '(dry) field' (pJ * $-k a$ place suffix, $\mathrm{pJ}{ }^{*}-i$ substantivizer) J hata 2.4 , OJ pata '(dry) field'5

J hatake (3.7a b), oJ patake 2 'field, farm, plantation, garden,' Shuri (Okinawa) hataki, Naze (Amami) hatə,, Ishigaki (Yaeyama) patagi, Oura (Miyako) patagi, Yonaguni hatagi, pR *patake 'field, croft'

The Turkic word pTk * $(p)$ atï *(p)ata 'irrigated field for cultivation' can be reconstructed, considering pTk *(p)ati-z 'watered fields' and pTk *(p)ata-g 'island' as reflexes of the same etymon, where pTk ${ }^{*}-z$ represents a dual and collective suffix (e.g., in paired body parts such as от kö-z 'eyes,' ti-z 'knees,' agï-z 'lips' and kökü-z 'breasts,' ethnonyms such as от оgu-z and kïrg̈̈-z, and sets of more than one such as iki-z 'twins,' üc-üz 'triplet,' dörd-üz 'quadruplet' and undefined quantities such as от yultu-z 'stars', yilldi-z 'roots') and pTk *$(A) g$ a petrified place suffix (e.g., pTk *o:t 'fire' $\rightarrow$ o:t-ag 'tent, dwelling place'). The alleged loss of the initial labial stop * $p$ - cannot be confirmed since we lack a Khalaj cognate. The reconstruction of the final low vowel in pTk ${ }^{*}(p) a t a$ is supported by the vowel in the Mongolic borrowing pMo *atar 'uncultivated land.' Contrary to Poppe (1960: 51, 82), Menges (1984: 284), and Starostin et al. (2003: 1127), I do not think that the Mongolic form reflected in WMo atar 'unploughed or fallow field,' Khalkha atar, Buriat atar and Monguor ator is a cognate. Indications of borrowing are the lack of initial $f$-in the Monguor form atar, which would be the expected reflex of pMo * $p$ - (e.g., pMo *poro- 'to entwine' and its Monguor reflex furō- in (4)) and the fact that the Mongolic form is unsegmentable in spite of the morphological complexity of the Turkic form. In Korean, commonly, non-rising low monosyllabic place nouns ending in $-k$ or $-h$ are reductions from disyllabic forms with a place suffix ${ }^{*}-(\dot{t} / \Omega) k$ in the second syllable (Martin, 1996: 44-45), e.g., MK pask 'outside' (< * pası-k), math 'yard' (< *matı-k), alph 'front' (< *alpı-k), etc. The lack of aspiration in the derivation $\mathrm{k}$ patwuk 'stone checkers (game)' (< * pat tolk 'field stones') may be indicative of the word for 'field' without place suffix. Finally, in Japonic, pJ "pata-ka-i 'field, plantation' is probably derived from pJ *pata '(dry) field' by means of the place suffix $\mathrm{pJ}{ }^{*}-k a$, which occurs also in oka 'hill', arika

5 See fn. 4 for an explanation of the encoding of prosodic classes in Japanese (letter/number notation) in this and subsequent examples. 
'whereabouts', sumika 'residence,' etc. The sharing of a corresponding place suffix on the word for 'field' in Turkic, Koreanic and Japonic may indicate that the derivation goes back to proto-Transeurasian.

\subsection{Weaving activities in Transeurasian}

Two examples of cognate verbs with the meaning 'to twine' and 'to weave' are given in (3) and (4). Excavators of Xinglongwa sites have found circular clay disks measuring about $5 \mathrm{~cm}$ and having a hole in the center, which they associated with spinning and weaving activities and the exploitation of animal hair or plant fibers such as kuzu or nettle (Zhongguo, 1997: 64; Shelach, 20oo: 386; Underhill, 2013: Fig. 3.3). These findings corroborate the reconstruction of proto-Transeurasian verbs for 'to weave.' Twining can produce cloth, string or rope. Cord for making traps and nets has been found in a number of upper Paleolithic sites across the world (Tedlock, 2009: 66; Soffer et al., 2000: 512-514). Whereas twining is not necessarily linked to agriculture, weaving certainly is: there are no pre-agricultural textiles because weaving is labor-intensive and technologically complex, requiring a loom system. Only a society with food surplus can invest in the technology and labor it requires (Barber, 1995).

(3) pTEA *nap- 'to twine'

a. Turkic: pTk *yap (a)- 'to put (things) together, to string or twine animal fibers' от (Karakhanid) yap- '1 to build (e.g., a wall), to shut (a door), to cover (things), to stick (things) together,' yap 'matted wool,' yapyut 'cloth of camel wool', yapaqu 'refuse of wool; when the hair on the head becomes matted,' MTk. yap- '1,' yabaq 'a tuft of soft wool that serves as an absorbent cloth,' Kirgiz žap- '1,'̌̌a or filly in its first fall,' Kazakh žap- '1,' žabayi '2,' Nogai yap- '1,' yabayi '2,' Bashkir yap- '1,' yabayi '2,' Balkar žap-, žap-, zap- '1,' žabayi, zabayt '2,' Karaim yap- '1,'yapaya '2,' Karakalpak žap- '1,' žabayi '2,' Kumuck yap- '1,' yabayi '2,' Tatar yap- '1,' yabaya '2,' Azeri yap- '1,' yapaq, yapayi ' 3 wool, especially the wool of a sheep shorn in the spring,' Turkmen yap- '1,' yapaGi '3,' Uzbek yop- '1,' žabiqa '3,' Uighur yap- '1,' Khakas čap- '1,' čabiy '4 covering, cloth,' Yakut sap- '1,' sabi '4,' Dolgan hap- '1,' habi: '4,' Shor čap- '1,' Tuva št $t p-$ ' 1 '

b. Tungusic: pTg *nap- 'to make rope'

Ulcha lāxị, Orok lāpu, Nanai lāpị, Oroch lappi 'tiers, straps (for skis)' < pTg *lapki 'tiers, straps (for skis)' < "napki< *nap- 'to make rope' + *-ki resultative nominalizer (Robbeets, 2015: 407) 
c. Koreanic: $\mathrm{pK}^{*}$ "nap- 'to twine' K nah- 'spin (thread), make yarn (thread), weave (tr.),' к kkunapwul 'a string of cord' < kkun 'cord, string' + "nap- 'to twine' + -wul deverbal nominalizer, EMK $n a(h)$ 'string'

d. Japonic: pJ *nap- 'to make rope'

J nau (в), oJ nap- 'twist, plait, weave (into rope)'; J nawa (2.3), oJ napa 'rope,' Yonaguni nna в 'rope' < pJ *nap- + ${ }^{*}-a$ deverbal nominalizer (Sakakura, 1966: 286-303; Robbeets, 2015: 156)

The Karakhanid Old Turkic verb yap- has a variety of meanings, such as 'to build (e.g., a wall), to shut (a door), to cover (things), to stick (things) together,' but the common denominator seems to be 'to bring (things) together.' Given the numerous deverbal nouns referring to strings or cloths composed of animal fibers, I assume that the meaning 'to string or twine animal fibers' was among the original meaning of the verb pTk *yap $(a)$ -

The Tungusic words for 'tiers, straps (for skis)' all have an initial liquid $l$-, which seems to be an exception to the common absence of liquids in initial position in the Transeurasian languages. However, Poppe (1960: 74) has suggested that pTg ${ }^{*}$ - developed from an initial ${ }^{*} n$ - followed by a labial consonant (Robbeets, 2005:69). As I have identified pTg *- $k i$ as a resultative deverbal nominalizer (Robbeets, 2015: 407), the underlying verbal meaning appears to be 'make straps or rope.' As proto-Turkic did not allow a nasal in initial position, the regular correspondence to initial ${ }^{*} n$ - in the other Transeurasian languages is pTk ${ }^{*} y$ - The remaining sound correspondences are regular as well and lead to the reconstruction of pTEA *nap- 'to twine.'

\section{(4) pTEA *po:rs- 'to weave'}

a. Turkic: pTk *pö:r- 'to plait, weave' От (Karakh.) ör- 'to plait (hair or other fibers),' MTk. ör- '1 to weave, plait, twist things together,' örmek 'cloth woven from camel hair,' Kirgiz ör- '1,' Kazakh ör- '1,' Nogai ör- '1,' Bashkir ür- '1,' Karaim ör- '1,', Karakalpak $\ddot{o r}$ - '1,' Tatar $\ddot{o r}$ - 'to plait, to knit, to darn, to interlace, to interweave, to build (a wall), to lay bricks or stones in a building,' Turkish ör- '1,' Azeri hör- '1,' Turkmen örr- '1,' Gagauz yör- '1,' Uzbek or-, Uighur ö(r)-, Yakut ör-, örü 'plaiting,' Dolgan ör- 'to plait, bind together, wind,' örü 'plaiting,' Khalaj hiri-, hör- 'to plait,' Chuvash var 'best sort of flax,' vĕren 'cord, rope' 
b. Mongolic: pMo "poro- 'to entwine' in "poro-go- 'to wrap' ( ${ }^{*}-g A$ - causative) and "poro-ti- 'roll, rotate' (*-ti-intensive) WMo. oriya- '1 to tie around, entwine, wrap, bandage, wind, roll (tr.),' oruya- '1,' orči- '2 to turn around, roll, rotate (intr.),' MMo. hura- '1,'xorči-, horči-, orči- '2,' orčul- '2,' Khalkha orō- '1,' orči- '2,' Buriat orō- '1,' oršo- '2,' Kalmuck orā- '1,' orčz- '2,' Ordos orō- '1,' orčin 'around,' Dongxian xoro'1,' Baoan horz-, Dagur oré-, Shira-Yughur horō-, Monguor furō-, xurō- '1'

c. Tungusic: pTg "poro- 'to spin, weave (nets)' Evenki horol-' '1 to spin, whirl, go around,' Negidal xoyol-, xoyil- '1,', Udehe xo:li- '1,' Sibe forz-, foru- '1', Manchu foro- 'to turn round, turn over,' foringa- '1,' Olcha pori- 'to weave (nets),' porpun 'device for weaving nets', po:rfu 'spindle,' Oroch po:rpu, po:rfu 'spindle'

d. Koreanic: $\mathrm{pK}$ *oln 'unit of woven fibers, component of woven fabric' к o:l, М K "wol 'strand of rope, ply, warp,' к olk- 'to tie up, bind, weave' (< $\mathrm{pK}$ *oln 'woven fabric' $+\cdot k n$ - inchoative; Robbeets, 2015: 258)

e. Japonic: $\mathrm{pJ}$ *orz- 'to weave' $\mathrm{J}$ oru A 'weave,' OJ $\mathrm{oro}_{2} s$ - 'deign to weave,' Shuri qur- 'weave'

For Turkic it is commonly assumed that word-initial pTk ${ }^{*} p$ - developed into a bilabial fricative and further into $h$-, leaving only a trace in Khalaj $h$-, and finally disappeared in most of the contemporary Turkic languages. Given the attestation of Khalaj hör- 'plait' it is legitimate to reconstruct pTk * pörr- 'to plait, weave.'

The initial labial stop pMo ${ }^{*} p$ - is regularly preserved in the peripheral Mongolic languages, notably as $f$-in Monguor furō-, as $h$-in Shira-Yughur horō- or Baoan horz- and as $x$ - in Dongxiang xoro-, but it disappeared in the central Mongolic languages.

In Tungusic, the regular reflexes of $\mathrm{pTg}^{*} p$-are Nanai/Olcha/Orok $p$-, Manchu $f$-, Evenki/Even $h$-, Negidal/Oroch/Udehe $x$ - and Solon $\emptyset$ (Benzing, 1956: 981). Except for Oroch po:rpu, po:rfu 'spindle,' which is probably a borrowing from Olcha, the cognates thus correspond regularly and suggest the reconstruction of an initial pTg * $p$-.

In proto-Japonic and proto-Koreanic, the expected reflex of pTEA ${ }^{*} p$ - is * $p$ - (Robbeets, 2005: 373). However, an initial labial stop sporadically drops before a (long?) rounded $\mathrm{pJK}{ }^{*} o(:)$, as it probably also did in the reflexes of pTEA *bo:l- 'to sit down, become, be' in Japanese and Korean (Robbeets, 2015: 159-163). Since Old Japanese makes no distinction between $o_{1}\left(<{ }^{*} o\right)$ and $o_{2}$ 
$\left(<{ }^{*} \partial\right)$ in initial position, I have opted for * $o$ in pJ *ora- 'to weave' because it entails a regular correspondence (Robbeets, 2015: 128). The root-final vowel of $\mathrm{pJ}$ *orz- is an irregular fit, which may be due to vowel reduction in root-final position.

\subsection{Coastal subsistence in Japano-Koreanic}

Three examples of shared coastal subsistence terms are given in (5), (6) and (7). As 35 оо вС is regarded as the approximate time that millets were transmitted from the Liaodong Peninsula to the Korean Peninsula, I associate the earlier (i.e., before 3500 BC) Houwa sites in Liaodong with speakers of JapanoKoreanic and the later (i.e., after $3500 \mathrm{BC}$ ) ones with speakers of Japanic. At the Houwa sites, several sherds from canoe-shaped pottery were unearthed. The fact that they were made in the shape of a dugout canoe indicates that canoes or boats already existed. These boats were used mostly for fishing, but they also served as a means of transportation on the sea-as early as 5000600 вс, given the early start of economic exchanges between the Liaodong and Shandong Peninsulas. In addition, large fishing net weights as well as bones of large marine creatures such as whales and sharks were found (Xu, 1995: 85). This indicates that people fished not only close to the shore but also in distant seas.

(5) pJK *pona 'boat'

a. Koreanic: pK "pani $($ ? < "pınye <? "pune $)$ к pay, Mк ·poy 'boat'

b. Japanic: pJ "puna 'boat'

J fune (2.4), OJ pune 'boat' J funa-, OJ puna- 'boat-,' Onna (Northern Okinawa) puuni $\mathrm{B}$, Yonaguni nni $\mathrm{C}$

If the final high front vowel of $\mathrm{pK}$ "pani can ultimately be derived from a mid vowel, perhaps through breaking of the ${ }^{*} i$, all sound correspondences would be regular. The original stem-final * $a$ in pJ "puna 'boat' is preserved in numerous Japanese compounds, such as hunako 'boatsman' and hunadana 'a stepping board on a dug-out canoe.' I do not exclude that $\mathrm{pJK}$ "puna 'boat' was originally a loan from proto-Sinitic, given the reconstruction oc 舫 " $p^{\uparrow} a y$-s 'boat' (Baxter and Sagart, 2011). In line with Whitman (1985: 156-158, 187, 211), I regard the above words as cognates, whereas oJ $p e_{2}$ 'prow/front part of a boat' is probably an early borrowing from the predecessor of $\mathrm{MK}$. poy 'boat.' 
a. Koreanic: pK *pok 'swellfish, Takifugu chinensis' к pok 'swellfish, Takifugu chinensis'

b. Japonic: pJ "puku 'swellfish, Takifugu chinensis' J hugu (2.5), oJ puku 'swellfish, Takifugu chinensis'

The swellfish inhabits marine waters around China, Korea, and Japan. It is most prevalent in the Bohai Sea, Yellow Sea, and East China Sea, followed by the Sea of Japan. The swellfish thus appears to radiate around the Liaodong Peninsula, which supports the proposition that the original Japano-Koreanic speech community was located in that area. Assuming final vowel loss in Korean, the correspondences are regular; see Robbeets (2015: 125) for the vowel correspondence.

\section{pJK *keni 'crab, Portunus trituberculatus'}

a. Koreanic: $\mathrm{pK}^{*}$ keni 'crab, Portunus trituberculatus' $\mathrm{k} k e y$, dialect kengi, $\mathrm{m \kappa}$ " $k e y$ 'crab'

b. Japonic: $\mathrm{pJ}$ *kani 'crab, Portunus trituberculatus' J kani (2.1), oJ kani, Narada gani o, Ibuki-jima gane (2.1), Shodon (Amami) ganyi A, Shuri (Okinawa) gani A, Irabu (Miyako) kaN A, Ishigaki (Yaeyama) kaN A, Yonaguni kaNna c (< pR *kani-wa crab-DIM), pR *kani *gani 'crab'

The ecology of the Japanese blue crab or horse crab is similar to the swellfish in that it is found off the coasts of Japan, Korea, China and also Taiwan. The attestation of dialectal forms such as kengi supports the reconstruction of a medial nasal in $\mathrm{pK} *$ keni. The comparison with $\mathrm{pJ}{ }^{*} k a n i$ is commonplace in linguistic literature and the correspondences are regular.

\subsection{Rice in Japanic under Austronesian influence}

The Transeurasian languages lack a common rice vocabulary. In Japonic many words relating to rice agriculture can be derived language-internally. For instance, oJ momi 'hulled rice,' oJ ipi ' 'steamed rice, cooked millet' and oJ nuka 'rice bran' seem to be deverbal nouns, from the original verbs underlying oJ mom- 'rub,' MJ if- 'to eat' and oJ nuk- 'remove,' respectively (see Robbeets, 2017a). 
The analysis of oJ ipi ' 'steamed rice, cooked millet' along these lines is given in Vovin (1998: 371-372) and Robbeets (2005: 552). Interestingly, parallel formations of 'cooked rice' are found in Old Chinese and Austronesian. Old Chinese 飯 *bon?-s 'cooked rice or millet,' for example, is reconstructed as a deverbal noun in -s from the verb 'to eat' (Baxter and Sagart, 2011). Similarly, protoSino-Tibetan *ka-n 'cooked rice,' which is reflected in Old Chinese 飫 * $C . q^{\varsigma} a n$ 'thick gruel of rice' and proto-Tamang ${ }^{B}$ kan 'cooked rice,' is reconstructed as a deverbal noun in $-n$ from a proto-Sino-Tibetan verb * $k a$ 'to eat' (Sagart, 2003: 129-130). Moreover, the word for 'cooked rice' in some Austronesian languages, such as Yami of Orchid Island, is kanen 'cooked rice,' which, according to Sagart (2003:130), can be derived from the proto-Austronesian verb *kaen 'to eat' and the object nominalizer *-en.

The parallel formations may be due to universal principles in linguistic structuring, as it seems obvious to use a general term for 'food' for the most common dietary product. However, given the relative concentration of this formation in Sino-Tibetan, Austronesian, and Japanese, I do not exclude combinational borrowing across these languages. If that is indeed the case, the recurrent character of the formation in Sino-Tibetan would indicate Sinitic as the most probable source of diffusion.

I also do not exclude the possibility that $\mathrm{pJ}$ * $i p i$ 'steamed rice, cooked millet' was ultimately borrowed into Koreanic as $\mathrm{pK}$ * $i p i>$ > $" p i>$ " pye 'rice,' after 150 о вС when rice agriculture was transmitted to the Korean peninsula. Note that $i$ breaking seems a common phenomenon in Korean, e.g., M K khi- khye- hhye'to kindle' and $\mathrm{MK} n i$ - 'go' nye- 'go around.'

The following data in (8)-(9) illustrate rice-related items that correlate across Austronesian and Japanic, suggesting an Austronesian influence on the latter. The Ryukyuan cognates in (8.2) and (9.3) indicate that the presumed borrowing took place before the separation between Mainland Japanese and Ryukyuan, that is, before Japonic reached the Japanese Islands. ${ }^{6}$

6 I am essentially in agreement with Pellard's (2015) classification of the Ryukyuan family (see also Robbeets, 2015: 30): Ryukyuan separated from Mainland Japanese on Kyushu, according to Lee and Hasegawa's (2011) Bayesian phylogenetic analysis, in 182 BC. This means that protoRyukyuan was spoken on Kyushu for about a millennium until proto-Ryukyuan speakers moved southward to settle in the Ryukyu Islands around 9ooAD. The presumed borrowing from Austronesian into the common ancestor of Mainland Japanese and Ryukyuan thus dates this influence well before $182 \mathrm{BC}$, probably even before $900 \mathrm{BC}$, when proto-Japonic is thought to have reached Japan. 
(8.1) Austronesian: pAN *lusuy '(rice) mortar' (Blust, 2015)

a. Formosan

Bunun [Paiwanic] nusuy, Pazeh [Paiwanic] tuzuך, Tamalakaw [Puyuma] lusuy 'mortar'

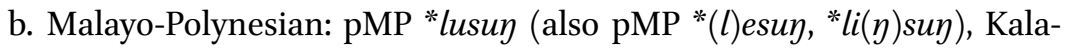

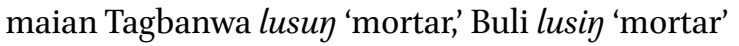

(8.2) Japanic: $\mathrm{pJ}$ *usu '(rice and grain) mortar'

J usu (2.4), oJ usu 'mortar for grain, rice cakes and making purified alcohol,' Shuri quuşi в, Yonaguni uci 'mortar'

Benedict (1990: 155, 211) regards the Japanese and Austronesian terms for 'mortar' as cognates. However, considering that $\mathrm{pJ}$ * $u s u$ is the closest possible imitation of pAN *lusug given the absence of initial liquids and word-final nasals in proto-Japanese, prehistorical borrowing is at least as likely. There are a number

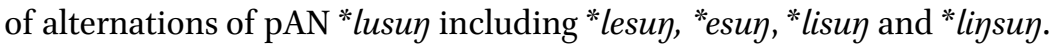

(9.1) Old Chinese: oc 糜 *C.maj 'rice gruel; destroy, crush' (Baxter and Sagart, 2011)

(9.2) Austronesian: pAN *Semay 'cooked rice' (Blust, 2015)

a. Formosan

Pazeh sumay 'cooked rice,' Amis hmay 'cooked rice,' Kavalan maay 'cooked rice'

b. Malayo-Polynesian: pMP *hemay 'cooked rice'

Aklanon humáy 'cooked rice,' Ata homoy 'cooked rice,' Manabo (Ilianen) imiy 'cooked rice,' Manabo (Tigwa) himiy 'cooked rice,' Subanun (Sindangan) gimai 'cooked rice,' Bikol húmay 'prepare a rice dish in which meat or fish are cooked,' Cebuano humáy 'general term for rice,' Isneg ammáy 'rice (Oryza sativa), unhusked rice, paddy,' Sangir ěmme 'rice in the field, unhusked rice; food (in general),' Atta ammay 'rice on the stalk,' Toba Batak ome 'rice in the husk, rice plant,' Itawis ammáy 'rice plant,' Hiligaynon humáy 'rice plant'

(9.3) Japanic: pJ *komai 'dehusked rice'

J kome (2.3), oJ kome 2 'dehusked rice,' Nakazoto mee A, Miyako maz, Yonaguni mai $\mathrm{A}$ 
Benedict (1990: 155, 233) and Kawamoto (1984: 42) consider the Japanese word for 'dehusked rice' a cognate rather than a borrowing of the proto-Austronesian form. This pAN form *Semay 'cooked rice' is reconstructed by Blust (2015) on the basis of Formosan and Western Malayo-Polynesian forms. Only one Formosan language preserves the initial $s$-, all others have lenited it; as the development of $s$ into $h$ is a universally frequent lenition process, it may have been on its way in para-Austronesian as well. Para-Austronesian *hemay 'cooked rice' would be the most probable model for $\mathrm{pJ}$ *kamai 'dehusked rice,' as proto-Japonic lacks a velar fricative ${ }^{*} h$. Sagart (2011) further points out that Amis hmay 'cooked rice' is the expected reflex of pAN *hemay rather than *Semay.

The ultimate source of borrowing may be in the proto-Sinitic form ancestral to the Old Chinese word 糜 *C.maj 'destroy, crush, rice gruel.' The cognate in Written Tibetan dmyalba 'to cut up into small pieces' (Schuessler, 2007: 381) suggests that the original proto-Sino-Tibetan meaning was 'to cut in small pieces, crush' and that the meaning 'rice gruel,' also reflected in the Southern Min languages, is a secondary development in proto-Sinitic after its separation from proto-Tibeto-Burman around 4000 ВС. This is reminiscent of English, where gruel and grout 'cooked grains' can be derived from grit 'crushed stones.' Since only the secondary meaning of this word is shared with Austronesian and Japanese, I am inclined to take the proto-Sinitic word as the ultimate model and assume that the borrowing took place between $3000 \mathrm{BC}$, the time of the introduction of rice agriculture to Shandong, and $1300 \mathrm{BC}$, the time that rice agriculture was transmitted to the Korean Peninsula.

A part of this borrowing scenario has been proposed by Sagart (2011: 126127), but diffusion from proto-Sinitic into Austronesian is in contradiction with his view, as he relates pAN *Semay 'cooked rice' with oc ${ }^{*}{ }^{*} C . m^{\varsigma}[e] j$ ? 'rice grains, dehusked and polished' and Proto-Bodo-Garo *mai1 'rice, paddy, cooked rice' (Sagart, 2005: 167; 2011). However, in Baxter and Sagart (2011: 91), the Old Chinese form appears as ${ }^{*} C \cdot m^{\wedge} i j$ ? with a less satisfactory vowel match, and the Old Chinese syllable type A is expected to correlate with an Austronesian voiceless stop, rather than a fricative. Therefore, the proto-Sinitic form ancestral to oc * C.maj 'destroy, crush, rice gruel' seems a better match, albeit from a borrowing perspective.

Apart from the etymology proposed for oc 米 ${ }^{*} C \cdot m^{\Upsilon}[e] j$ ? 'rice grains, dehusked and polished,' there is only one other proposed Sino-Tibetan-Austronesian cognate set relating to rice agriculture, which has the meaning husked rice': pAN *beRas, oc 糲 ma-rSat-s and Tibetan mbras 'rice' (Sagart et al., this issue; Sagart, 2005: 167). However, again, this etymology looks like a borrowing rather than a cognate set because, in violation of the expected sound corre- 
spondence that leaves out non-final syllables of Austronesian words, the first syllable of the Austronesian word is reflected in Sino-Tibetan.

Sagart's reconstruction of rice vocabulary in Sino-Tibetan-Austronesian seems in conflict with the view that rice was integrated rather late into the millet cultural assemblage in northeast China and that it was transmitted separately into the Yangshao and Dawenkou cultures, unless his reconstructed items refer to the cultivation of rice that was not yet domesticated. If, on the other hand, the rice terms were indeed borrowed, they support the transmission of rice agriculture from Yangshao in the west to Dawenkou in the east, rather than a southern coastal root. It would be more reasonable to associate Sino-Tibetan-Austronesian with the Setaria millet cultivators of the Peiligang, Cishan and Houli cultures in the 7 th millennium BC. Such an early date for the unity is in line with the great divergence of the cognates and the relatively high degree of cognate attrition. It also accounts for the problematic nature of the two alleged cognates relating to rice agriculture in (8) and (9). Moreover, it seems to align with Ko and his colleagues' (2014: 430) dating of a separation between Austronesian and Sino-Tibetan populations around 6оoо-80оо вС.

(10) shows another candidate for borrowing of grain-related vocabulary from Austronesian into Japanic. This item has reflexes in Koreanic as well, which confirms the presumed dating of the Austronesian influence to the time Japanic was still spoken on the mainland.

(10.1) Austronesian: pAN *baCaR 'Panicum miliaceum' (Sagart et al., this issue; Blust, 2015)

a. Formosan:

Saisiyat (Ta'ay) basaL 'Panicum miliaceum' Saisiyat (Tungho) basa: 'Panicum miliaceum'

Bunun batal 'Panicum miliaceum'

Atayal (Skikun) bacax 'Panicum miliaceum'

Rukai (Maga) bcaa 'Panicum miliaceum'

b. Malayo-Polynesian:

Makassarese batara? 'millet spp.'

Tetun batar 'maize'

(10.2) Japanic: pJ "wasara *wasara 'early ripening crop, early ripening rice' $\mathrm{J}$ wase (2.4?), OJ wase 'an early ripening variety; ripening early, precocious; early-ripening variety of rice plant,' J wasa-mono 'early produce,' OJ wasa-ipi $i_{1}$ 'rice cooked from early rice,'wasa-po 'early ears of 
grain/rice,' wasa-ki $i_{2}$ 'rice wine made from early rice'; oJ $w_{0 s o_{2}}$ 'precocious, early ripening,' oJ $\mathrm{woso}_{2} \mathrm{ro}_{2}$ 'precocious, early ripening'

(10.3) Koreanic: pK *pısal 'hulled variety of grain, rice' (Vovin, 2015)

K ssal, MK .psol 'rice, hulled variety of grain,' e.g., K ssal poli 'hulled barley'; poli ssal 'a grain of barley, a barley corn' (with poli 'barley'), copssal 'millet grain' (with co 'millet'), LOK 菩薩 "pasal 'rice' (LMC 菩 薩 phuă sar)

Sagart et al. (this issue) convincingly reconstruct pAN *baCaR 'broomcorn millet (Panicum miliaceum). Japonic leaves room for the reconstruction of a phonologically similar form $\mathrm{pJ}$ "wasara 'early ripening crop, early ripening rice.' As proto-Japonic lacked a voicing distinction as well as an affricate $t s$ before the vowel $a$ and a word-final ${ }^{*}-r$, pJ ${ }^{*} w-$, ${ }^{*}-s$ - and ${ }^{*}-r a$ represent the closest possible imitation of pAn ${ }^{*} b-$, ${ }^{*}-c$ - and ${ }^{*}-r$. The reconstruction of a three-syllabic root in proto-Japonic is very rare and indicative of borrowing. Given attested meanings in Old Japanese that do not necessarily relate to rice, such as in oJ wase 'an early ripening variety; ripening early, precocious; early-ripening variety of rice plant,' J wasa-mono 'early produce' and wasa-po $o_{1}$ 'early ears of grain/rice,' it is likely that the original form meant 'early ripening variety of any crop.' Since the speakers of proto-Japanic were already familiar with broomcorn millet (Panicum miliaceum), they may have borrowed the Austronesian word in the sense of 'early ripening variety of Panicum miliaceum,' perhaps because, being situated to the south, the farmers on Shandong were able to collect their crops earlier than the people on Liaodong. Over time, the Japonic meaning got extended to any 'early ripening crop' including 'early ripening rice.' Vovin (2015) reconstructs $\mathrm{pJ}$ "wasay 'early rice' and proposes that the proto-Japonic form was borrowed into proto-Koreanic "pusal 'rice.' However, he recognizes that this reconstruction is problematic: " $\mathrm{i}] \mathrm{f} \mathrm{PK}$ *pasar is a loan from PJ *wasay, one has to explain how proto-Koreanic has got its final *-r from PJ ${ }^{*}$-y"7 (Vovin, 2015: 234). This issue can be solved by taking into consideration the vowel alternation between oJ wasa-and woso $_{2}$ 'precocious, early ripening' in addition to the fact that woso $_{2}$ 'precocious, early ripening' is attested next to oJ $w^{2} o_{2}$ $\mathrm{rO}_{2}$ 'precocious, early ripening.' The alternation with $\mathrm{pJ}$ *wasarə supports the reconstruction of $\mathrm{pJ}$ "wasara 'early ripening crop' with a final liquid syllable.

7 Vovin reconstructs pK *pasar for 'rice,' but both the Late Old Korean reconstruction *prsal 'rice' and Ramsey's law on minimal vowel reduction indicate the reconstruction $\mathrm{pK}$ *pasal with a minimal vowel. 
The final syllable may have dropped by way of its reanalysis as $\mathrm{pJ}{ }^{*}-r a \sim-r z$ as the suffix deriving property nouns from verbal adjectives; see Robbeets (2015: 339-346). The vowel alternation between pJ "wasara and "wasara may be due to labial assimilation of the initial vowel, followed by a restriction on the shape of Old Japanese root morphemes whereby the vowel $o_{2}$ cannot occur in a root together with the vowels $u, o_{1}$ or $a$, a phenomenon known as Arisaka's law. The Japonic word is not reflected in the Ryukyuan languages.

The reconstruction of $\mathrm{pJ}$ "wasara 'early ripening crop, early ripening rice' strengthens Vovin's (2015) suggestion that the form was borrowed into protoKoreanic as "pasal 'rice.' The direction of the borrowing from Japonic into Koreanic is supported by the observation that $\mathrm{pJ}{ }^{*} w$ - was borrowed as $\mathrm{pK}{ }^{*} p$-, given that Japonic had both ${ }^{*} w$ - and $*$-, while Koreanic had only ${ }^{*} p$-. Similar to the Japonic model, the Koreanic word can be used in reference to any crop, including rice. The direction of the borrowing from Austronesian into Japanic into Koreanic parallels the route of dispersal of rice agriculture from Shandong to Liaodong to the Korean Peninsula, as illustrated in Fig. 5 .

\section{Conclusion}

In this paper, I proposed a hypothesis reconciling Austronesian influence and Transeurasian ancestry in the Japanese language, explaining the spread of the Japanic languages through farming dispersal.

Two problems became apparent when examining the observation that the Japanese language reflects historical connections with the Transeurasian and with the Austronesian languages. First, there was no credible scenario that identifies a homeland and a dispersal route for the Transeurasian languages. Second, Hudson's $(1996,2012)$ findings about the lack of archaeological support for a prehistoric Austronesian settlement on the majority of the Japanese Islands appeared to contradict previous claims about a Jōmon-Pacific connection.

In an attempt to formulate a solution for these problems, I first linked demographic dispersals associated with agriculture to linguistic dispersals in northeast Asia and then provided additional support based on a paleo-linguistic reconstruction of subsistence terms. Integrating archaeology and linguistics into a single approach, I suggested an alternative way to reconcile the linguistic connections of Japanese with what is known about the Neolithic in northeast Asia. My hypothesis acknowledged both the Austronesian and Transeurasian characteristics of the Japanese language by explaining them as an interplay of areal and inherited properties. 
The outcome of my research is as follows. First, I proposed that the homeland of the Transeurasian language family was in the West Liao River Basin

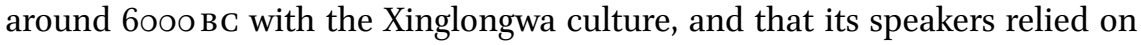
a broad-spectrum subsistence strategy, adopting agriculture and growing nondomesticated millets, but also collecting roots and nuts in the wild. Although the terms for domesticated cereals tend to be fairly stable among the populations who domesticated them, the terms for 'broomcorn millet' and 'foxtail millet' cannot be reconstructed to proto-Transeurasian. This may be due to the fact that the proto-Transeurasian community was less focused on agriculture than, for instance, the cultures in the Yellow River Basin. It may also be explained by the fact that speakers of Turkic, Mongolic and Tungusic languages abandoned agriculture in favor of a more animal-oriented subsistence strategy, leading to the loss of agricultural terms in those languages and their preservation in Japanese or Korean only. The latter explanation is supported by Savelyev (2017), a study of secondary phenomena of derivation, lexical recycling of previously agricultural vocabulary and borrowing in the creation of Turkic and Altaic pastoralist terms.

Second, I argued that farming provides a motivation for the expansion of the Transeurasian languages. However, the spread of farming with language does not necessarily imply demographic growth. Although the primary separation between Altaic and Japano-Koreanic may indeed have been driven by population increase and scarcity of resources, subsequent splits associated with the spread of millet agriculture, such as the spread of Tungusic or Koreanic, find a better explanation in the versatile climate in the region. Relying on a variety of food production strategies, including hunting, gathering, fishing, and plant cultivation, helped the Transeurasian populations to expand into different natural environments. As these populations encroached on the coasts of the Bohai Sea and the Sea of Japan, maritime strategies became more important. This is reflected in the maritime vocabulary reconstructed for JapanoKoreanic and some semantic developments in Tungusic, such as 'to make nets' from 'to weave.'

Third, I found that farming can also explain prehistorical connections between Japanic and Austronesian, albeit within a borrowing context. As the speakers of proto-Japanic were already familiar with millet farming, the integration of rice cultivation into the agricultural package did not result in language shift, but rather in borrowing. One of my main claims is that a paraAustronesian language was spoken on the Shandong Peninsula, while the homeland of Japanic was situated on the Liaodong Peninsula between the third and second millennium $\mathrm{BC}$, with its speakers adopting rice agriculture and Austronesian borrowings within the Liaodong-Shandong interaction sphere. 
My current proposal is only a working hypothesis that remains to be tested by interdisciplinary tools. Future research strategies should, among others, include computational phylolinguistic analysis, paleo-linguistic reconstruction, archaeological comparison of Neolithic and Bronze Age cultures in East Asia, and a model-based genetic analysis including genome-wide autosomal DNA. There is much work to be done to bring together linguistic, archaeological and genetic evidence. In the future, I hope to contribute to this enterprise in my eurasiazangle project "Millet and beans, language and genes. The dispersal of the Transeurasian languages," which is funded by an ERC Consolidator Grant.

$\begin{array}{ll} & \text { Abbreviations } \\ \text { EMK } & \text { Early Middle Korean } \\ \text { J } & \text { Japanese } \\ \text { K } & \text { Korean } \\ \text { LMC } & \text { Late Middle Chinese } \\ \text { LOK } & \text { Late Old Korean } \\ \text { MK } & \text { Middle Korean } \\ \text { MMo. } & \text { Middle Mongolian } \\ \text { MTk. } & \text { Middle Turkic } \\ \text { OC } & \text { Old Chinese } \\ \text { OJ } & \text { Old Japanese } \\ \text { OT } & \text { Old Turkic } \\ \text { pAN } & \text { proto-Austronesian } \\ \text { pJ } & \text { proto-Japonic } \\ \text { pK } & \text { proto-Koreanic } \\ \text { pMo } & \text { proto-Mongolic } \\ \text { pMP } & \text { proto-Malayo-Polynesian } \\ \text { pR } & \text { proto-Ryukyuan } \\ \text { pTEA } & \text { proto-Transeurasian } \\ \text { pTg } & \text { proto-Tungusic } \\ \text { WMo. } & \text { Written Mongolian } \\ & \\ \rightarrow & \text { is derived as } \\ > & \text { develops into } \\ & \end{array}$




\section{Acknowledgements}

I am grateful to Tao $\mathrm{Li}$, my colleague at the eurasiazangle project, for providing me with Chinese sources in support of the hypothesis that the Dawenkou culture can be connected with Austronesian elements. The research leading to these results has received funding from the European Research Council (ERC) under the European Union's Horizon 2020 research and innovation program (grant agreement No 646612) granted to Martine Robbeets.

\section{References}

Ahn, Sung-Mo. 2010. The emergence of rice agriculture in Korea: Archaeobotanical perspectives. Archaeological and Anthropological Sciences 2: 89-98.

Arbi, Ezrin, Rao Sreenivasaiah Purushothama, and Omar Saari. 2015. Austronesian architectural heritage and the grand shrines at Ise, Japan. Journal of Asian and African Studies 5o(1): 7-24.

Barber, Elisabeth Wayland. 1995. Women's Work: The First 20,ooo Years: Women, Cloth, and Society in Early Times. London: Norton.

Barnes, Gina. 2015. Archaeology of East Asia: The Rise of Civilization in China, Korea and Japan. Oxford: Oxbow Books.

Bawden, Charles. 1997. Mongolian-English Dictionary. London: Routledge.

Baxter, William and Laurent Sagart. 2011. Old Chinese reconstruction, version of $20 \mathrm{Feb}-$ ruary 2011. Accessible at https://www.researchgate.net/publication/265110209_ Baxter-Sagart_Old_Chinese_reconstruction_version_of_2o_February_2011 (accessed August 28, 2017).

Bellwood, Peter. 1997. Prehistory of the Indo-Malaysian Archipelago. Revised edition. Honolulu: University of Hawai'i Press.

Bellwood, Peter. 2005. First Farmers: The Origins of Agricultural Societies. Malden: Blackwell.

Bellwood, Peter. 2011. First Migrants: Ancient Migration in Global Perspective. Malden: Blackwell.

Bellwood, Peter and Colin Renfrew (eds.). 2002. Examining the Farming/Language Dispersal Hypothesis. Cambridge: McDonald Institute for Archaeological Research.

Benedict, Paul. 199o. Japanese/Austro-Tai. Linguistica Extranea, Studia 20. Ann Arbor: Karoma Publishers.

Benzing, Johannes. 1956. Die tungusischen Sprachen. Versuch einer vergleichenden Grammatik. Abhandlungen der geistes- und sozialwissenschaftlichen Klasse 11. Wiesbaden: Akademie der Wissenschaften und der Literatur.

Bestel, Sheahan, Gary W. Crawford, Li Liu, Jinming Shi, Yanhua Song, and Xingcan Chen. 
2014. The evolution of millet domestication, Middle Yellow River Region, North China: Evidence from charred seeds at the late Upper Paleolithic Shizitan Locality 9 site. The Holocene 24: 261.

Blench, Roger. 2008. Stratification in the peopling of China: How far does the linguistic evidence match genetics and archaeology? In Alicia Sanchez-Mazas, Roger Blench, Malcolm D. Ross, Ilia Peiros, and Marie Lin (eds.), Past Human Migrations in East Asia: Matching Archaeology, Linguistics and Genetics, Routledge Studies in the Early History of Languages $5,105^{-132 . ~ L o n d o n: ~ R o u t l e d g e . ~}$

Blust, Robert. 1996. Beyond the Austronesian homeland: The Austric hypothesis and its implications for archaeology. In Ward Goodenough (ed.), Prehistoric Settlement of the Pacific, 117-16o. Philadelphia: American Philosophical Society.

Blust, Robert. 2015. Austronesian Comparative Dictionary, version of 14 June 2015 . Accessible at http://www.trussel2.com/ACD/ (accessed June 16, 2015).

Brace, C. Loring and Masafumi Nagai. 1982. Japanese tooth size: Past and present. American Journal of Physical Anthropology 59: 399-411.

Cincius, Vera Ivanovna (ed.) 1975-1977. Sravnitel'nyj slovar'tunguso-man'čžurskich jazykov. Vol. 1-2. Moscow: Nauk.

Crawford, Gary W. and Gyoung-Ah Lee. 2003. Agricultural origins in the Korean Peninsula. Antiquity 77: 87-95.

Crawford, Gary W. and Chen Shen. 1998. The origins of rice agriculture: Recent progress in East Asia. Antiquity 72: 858-866.

Diamond, Jared and Peter Bellwood. 2003. Farmers and their languages: The first expansions. Science 300: 597-6o3.

Drennan, Robert and Xiangming Dai. 2017. Chiefdoms and states in the Yuncheng Basin and the Chifeng region: A comparative analysis of settlement systems in North China. Journal of Anthropological Archaeology 29(4): 455-468.

Han, Kangxin and Takahiro Nakahashi. 1996. A comparative study of ritual tooth ablation in Ancient China and Japan. Anthropological Sciences 104(1): 43-64.

Harunari, Hideji. 199o. Yayoi jidai no hajimari. Tokyo: University Press.

Harunari, Hideji and Mineo Imamura (eds.). 2004. Yayoi jidai no jitsu nendai. Tokyo: Gakusei-sha.

Heggarty, Paul and David Beresford-Jones. 2014. Farming-language dispersals: A worldwide survey. In Claire Smith (ed.), Encyclopedia of GlobalArchaeology, 1-9. New York: Springer.

Hudson, Mark J. 1996. Japanese and Austronesian: An archaeological perspective on the proposed linguistic links. In Keiichi Omoto (ed.), Interdisciplinary Perspectives on the Origins of the Japanese, 267-279. Tokyo: International Research Center for Japanese Studies.

Hudson, Mark J. 1999. Ruins of Identity. Ethnogenesis in the Japanese Islands. Honolulu: University of Hawai'i Press. 
Hudson, Mark J. 2012 'Austronesian' and 'Jōmon' identities in the Neolithic of the Ryukyu Islands. Documenta Praehistorica 39: 257-262.

Hunt, Harriet, Marc Vander Linden, Xinyi Liu, Giedre Motuzaite-Matuzeviciute, Sue Colledge, and Martin K. Jones. 20o8. Millets across Eurasia: Chronology and context of early records of the genera Panicum and Setaria from archaeological sites in the Old World. Vegetation History and Archaeobotany 17(1): $5^{-18 .}$

Jia, Xin, Shuangwen Yi, Yonggang Sun, Shuangye Wu, Harry F. Lee, Lin Wang, and Huayu Lu. 2017. Spatial and temporal variations in prehistoric human settlement and their influencing factors on the south bank of the Xar Moron River, Northeastern China. Frontiers of Earth Science 11(1): 137-147.

Janhunen, Juha. 1996. Manchuria: An Ethnic History. Mémoires de la Société FinnoOugrienne 222. Helsinki: Suomalais-Ugrilainen Seura.

Janhunen, Juha. 20o9. Reconstructing the language map of prehistorical Northeast Asia. In Klaus Karttunen (ed.), Anantam śāstram: Indological and Linguistic Studies in Honour of Bertil Tikkanen, Studia Orientalia 108, 283-305. Helsinki: SuomalaisUgrilainen Seura.

Johanson, Lars and Martine Robbeets. 2010. Introduction. In Lars Johanson and Martine Robbeets (eds.), Transeurasian Verbal Morphology in a Comparative Perspective: Genealogy, Contact, Chance, Turcologica 78, 1-5. Wiesbaden: Harrassowitz.

Kawamoto, Takao. 1979. Toward a comparative Japanese-Austronesian III. Bulletin of Nara University of Education 28: 1-20.

Kawamoto, Takao. 1982. Toward a comparative Japanese-Austronesian IV. Bulletin of Joetsu University of Education 1: 1-28.

Kawamoto, Takao. 1984. Two sets of sound laws between Japanese and Austronesian. Bulletin of Joetsu University of Education 3: 31-50.

Kawamoto, Takao. 1985. The language most probably related to Japanese. Bulletin of Joetsu University of Education 4: 97-115.

Kim, Juwon, Dongho Ko, D.O. Chaoke, Yonfeng Han, Lianyu Piao, and B.V. Boldyrev. 2008. Materials of Spoken Manchu. Altaic Languages Series 1. Seoul: Seoul National University Press.

Ko, Albert Min-Shan, Chung-Yu Chen, Qiaomei Fu, Frederick Delfin, Mingkun Li, HungLin Chiu, Mark Stoneking, and Ying-Chin Ko. 2014. Early Austronesians: Into and out of Taiwan. The American Journal of Human Genetics 94: 426-436.

Kumar, Ann. 2009. Globalizing the Prehistory of Japan. Languages, Genes and Civilization. Routledge Studies in the Early History of Asia. London: Routledge.

Kuzmin, Yaroslav V. 2013. The beginnings of prehistoric agriculture in the Russian Far East. Current evidence and concepts. Documenta Praehistorica 40: 1-12.

Lee, Gyoung-Ah. 2011. The transition from foraging to farming in prehistoric Korea. Current Anthropology 52(4): 307-329.

Lee, Sean and Toshikazu Hasegawa. 2011. Bayesian phylogenetic analysis supports an 
agricultural origin of Japonic languages. Proceedings of the Royal Society в 278: 36623669 .

Liu, Li, Neil A. Duncan, Xingcan Chen, and Ping Ji. 2016. Plant-based subsistence strategies and development of complex societies in Neolithic Northeast China: Evidence from grinding stones. Journal of Archaeological Science: Reports 7:247-261.

Liu, Xinyi, Martin K. Jones, Zhijun Zhao, Guoxiang Liu, and Tamsin C. O'Connell. 2012. The earliest evidence of millet as a staple crop: New light on Neolithic foodways in North China. American Journal of Physical Anthropology 149:1-8.

Maher, John C. 1996. North Kyushu Creole: A language-contact model for the origins of Japanese. In Donald Denoon, Mark Hudson, Gavan McCormack, and Tessa MorrisSuzuki (eds.), Multicultural Japan. Palaeolithic to Postmodern, 31-45. Cambridge: Cambridge University Press.

Martin, Samuel E. 1961. Dagur Mongolian: Texts and Lexicon. Bloomington: Indiana University Press.

Martin, Samuel E. 1996. Consonant Lenition in Korean and the Macro-Altaic Question. Honolulu: University of Hawai'i Press.

Martin, Samuel E., Yang-Ha Lee, and Sung-Un Chang. 1967. A Korean-English Dictionary. New Haven: Yale University Press.

Menges, Karl Heinrich. 1984. Korean and Altaic. A preliminary sketch. Central Asiatic Journal 28: 234-295.

Miller, Roy Andrew. 1971. Japanese and the Other Altaic Languages. Chicago: The University of Chicago Press.

Miyamoto, Kazuo. 20o9. Nōkō no kigen o saguru: Ine no kita michi. Tokyo: Yoshikawa kōbunkan.

Murayama, Shichirō. 1976. The Malayo-Polynesian component in the Japanese language. Journal of Japanese Studies 2: 413-435.

Murayama, Shichirō. 1978. Ist Japanisch eine Mischsprache? Ural-Altaische Jahrbücher 50: 111-115.

Nelson, Sarah. 1993. The Archaeology of Korea. Cambridge: Cambridge University Press.

Norman, Jerry. 2013. A Comprehensive Manchu-English Dictionary. Harving-Yenching Institute Monograph Series 85. Cambridge, MA: Harvard University Press.

Nugteren, Hans. 2011. Mongolic Phonology and the Qinghai-Gansu Languages. PhD dissertation, Leiden University.

Oppenheimer, Stephen. 1998. Eden in the East. The Drowned Continent of Southeast Asia. London: Weidenfeld \& Nicolson.

Palmer, Edwina. 2007. Out of Sunda? Provenance of the Jomon Japanese. Japan Review 19: $47-75$.

Pauly, Ulrich. 1980. Japan und die 'Kultur aus dem Süden': Vermutete Beziehungen Japans zu Südostasien und nicht-chinesischen Völkern Süd- und Ostchinas. Bonner Zeitschrift für Japanologie 2: 55-128. 
Pellard, Thomas. 2015. The linguistic archeology of the Ryukyu Islands. In Patrick Heinrich, Shinsho Miyara, and Michinori Shimoji (eds.), Handbook of the Ryukyuan Languages: History, Structure, and Use, 13-37. Berlin: De Gruyter Mouton.

Peterson, Christian and Robert Drennan. 2011. Patterned variation in regional trajectories of community growth. In Michael E. Smith (ed.), The Comparative Archaeology of Complex Societies, 88-137. Cambridge: Cambridge University Press.

Pietrusewsky, Michael, Adam Lauer, Cheng-Hua Tsang, Kuang-Ti Li, and Michele Toomay Douglas. 2014. Tooth ablation in early Neolithic skeletons from Taiwan. American Journal of Physical Anthropology 58: 207.

Poppe, Nicholas. 1960. Vergleichende Grammatik der altaischen Sprachen. Teil 1, Vergleichende Lautlehre. Porta Linguarum Orientalium, Neue Serie 4. Wiesbaden: Otto Harrassowitz.

Ramsey, Samuel Robert. 1993. Some remarks on reconstructing earlier Korean. Language Research 29: 433-441.

Ramsey, Samuel Robert. 1997. The invention of the Korean alphabet and the history of the Korean language. In Young-Key Kim-Renaud (ed.), The Korean Alphabet. Its History and Structure, 131-143. Honolulu: University of Hawai'i Press.

Ramstedt, Gustaf John. 19o6. Mogholica. Beiträge zur Kenntnis der Monghol-Sprache in Afghanistan. Journal de la Société Finno-Ougrienne. Helsinki: Suomalai-Ugrilainen Seura.

Ramstedt, Gustaf John. 1935. Kalmückisches Wörterbuch. Lexica Societatis FennoUgricae 111. Helsinki: Suomalai-Ugrilainen Seura.

Renfrew, Colin. 1987. Archaeology and Language: The Puzzle of Indo-European Origin. London: Jonathan Cape.

Robbeets, Martine. 2005. Is Japanese Related to Korean, Tungusic, Mongolic and Turkic? Turcologica 64. Wiesbaden: Harrassowitz.

Robbeets, Martine. 2015. Diachrony of Verb Morphology:Japanese and the Transeurasian Languages. Trends in Linguistics Studies and Monographs 291. Berlin: Mouton-De Gruyter.

Robbeets, Martine. 2017a. Proto-Transeurasian: where and when? Man in India 97: 1946.

Robbeets, Martine. 2017b. The Transeurasian languages. In Raymond Hickey (ed.), The Cambridge Handbook of Areal Linguistics, Cambridge Handbooks in Language and Linguistics, 586-626. Cambridge: Cambridge University Press.

Robbeets, Martine. Forthcoming. The language of the Transeurasian farmers. In Martine Robbeets and Alexander Savelyev (eds.), Language Dispersal beyond Farming, 93-122. Amsterdam: Benjamins.

Sagart, Laurent. 1995. Comments from Sagart. In: William S.-Y. Wang (ed.), The Ancestry of the Chinese Language, Journal of Chinese Linguistics monograph series 8, 337372. Hong Kong: Chinese University Press. 
Sagart, Laurent. 2003. The vocabulary of cereal cultivation and the phylogeny of East Asian languages. Bulletin of the Indo-Pacific Prehistory Association 23: 127-136.

Sagart, Laurent. 2005. Sino-Tibetan-Austronesian: An updated and improved argument. In Laurent Sagart, Roger Blench, and Alicia Sanchez-Mazas (eds.), The Peopling of East Asia: Putting together Archaeology, Linguistics and Genetics, 161-176. London: Routledge.

Sagart, Laurent. 2008. The expansion of Setaria farmers in East Asia. A linguistic and archaeological model. In Alicia Sanchez-Mazas, Roger Blench, Malcolm D. Ross, Ilia Peiros, and Marie Lin (eds.), Past Human Migrations in East Asia: Matching Archaeology, Linguistics and Genetics, Routledge Studies in the Early History of Languages 5, 133-158. London: Routledge.

Sagart, Laurent. 2011. How many independent rice vocabularies in East Asia? Rice 4(3): 121-133.

Sakakura, Atsuyoshi. 1966. Gokōsei no kenkyū [A study of word formation]. Tokyo: Kadokawa shoten.

Sakiyama, Osamu. 1996. Formation of the Japanese language in connection with Austronesian languages. In Takeru Akazawa and Emöke J.E. Szathmáry (eds.), Prehistoric Mongoloid Dispersals, 349-358. Oxford: Oxford University Press.

Sasaki, Kōmei. 1991. The Wa people and their culture in Ancient Japan: The cultures of swidden cultivation and paddy-rice cultivation. Acta Asiatica 6(1):24-46.

Savelyev, Alexander 2017. Farming-related terms in Proto-Turkic and Proto-Altaic. In Martine Robbeets and Alexander Savelyev (eds.), Language Dispersal beyond Farming, 117-148. Amsterdam: Benjamins.

Schuessler, Axel. 2007. ABC Etymological Dictionary of Old Chinese. Honolulu: University of Hawai'i Press.

Serafim, Leon. 1999. Reflexes of Proto-Korea-Japonic mid vowels in Japonic and Korean. Paper presented at the Workshop on Korean-Japanese Comparative Linguistics, XIVth International Conference on Historical Linguistics, Vancouver, BC, August 1999.

Shelach, Gideon. 20oo. The earliest Neolithic cultures of northeast China. Journal of World Prehistory 14: 363-414.

Soffer, Olga, James M. Adovasio, and David C. Hyland. 200o. The "Venus" figurines. Textiles, basketry, gender, and status in the Upper Paleolithic. Current Anthropology 41(4): 511-525.

Solheim, Wilhelm G. 1993. Four lobes of the Nusantao Maritime Trading Network. Paper presented at the 34th ICANAS conference, Hong Kong, August 1993.

Starostin, Sergej, Anna Dybo, and Oleg Mudrak. 2003. Etymological Dictionary of the Altaic Languages. Leiden: Brill.

Stevens, Chris J. and Dorian Q Fuller. 2017. The spread of agriculture in eastern Asia: Archaeological bases for hypothetical farmer/language dispersals. Language Dynamics and Change 7(2):152-186. 
Taylor, William T.T., Burentogtokh Jargalan, K. Bryce Lowry, Julia Clark, Tumurbaatar Tuvshinjargal, and Jamsranjav Bayarsaikhan. 2017. A Bayesian chronology for early domestic horse use in the Eastern Steppe. Journal of Archaeological Science 81: 4958 .

Tedlock, Barbara. 20og. The Woman in the Shaman's Body: Reclaiming the Feminine in Religion and Medicine. New York: Random House Publishing.

Underhill, Anne P. 2013. A Companion to Chinese Archaeology. London: Wiley-Blackwell.

Van Driem, George. 1998. Neolithic correlates of ancient Tibeto-Burman migrations. In Roger Blench and Matthew Spriggs (eds.), Archaeology and Language II, 67-102. London: Routledge.

Vovin, Alexander. 1994. Is Japanese related to Austronesian? Oceanic Linguistics 33:38739 o.

Vovin, Alexander. 1998. Japanese rice agriculture terminology and linguistic affiliation of Yayoi culture. In Roger Blench and Matthew Spriggs (eds.), Archaeology and Language II, 366-378. London: Routledge.

Vovin, Alexander. 2015. On the Etymology of Middle Korean psır 'rice.' Türk Dilleri Araştırmaları 25(2): 229-238.

Waterson, Roxana. [1990] 1997. The Living House: An Anthropology of Architecture in South-East Asia. Oxford: Oxford University Press.

Weber, Steven A. and Dorian Q. Fuller. 2008. Millets and their role in early agriculture. Pragdhara 18: 69-9o.

Whitman, John Bradford. 1985. The Phonological Basis for the Comparison of Japanese and Korean. $\mathrm{PhD}$ dissertation, Harvard University.

Wu, Rukang and John W. Olsen (eds.). 20o9. Paleoanthropology and Paleolithic Archaeology in the People's Republic of China. Walnut Creek: Left Coast Press.

Xu, Yu-Lin. 1995. The Houwa site and related issues. In Sarah Nelson (ed.), The Archaeology of Northeast China. Beyond the Great Wall, 65-88. London: Routledge.

Yang, Xiaoping, Louis A. Scuderi, Xulong Wang, Louis J. Scuderi, Deguo Zhanga, Hongwei Lia, Steven Forman, Qinghai Xu, Ruichang Wang, Weiwen Huang, and Shixia Yang. 2015. Groundwater sapping as the cause of irreversible desertification of Hunshandake Sandy Lands, Inner Mongolia, northern China. PNAS 112(3): 702-706. Downloadable at http://www.pnas.org/content/112/3/702.full.pdf (accessed September 4, 2017).

Yuan, Jing, Zhonghe Liang, Yun Wu, and Xiaobing Jia. 2002. Shell mounds in the Jiaodong peninsula: A study in environmental archaeology. Journal of East Asian Archaeology 4: 1-4.

Zhang, Chonggen. 20o9. Taiwan Shiju Shaoshu Minzu Yuanyu Dongyi Shuo Shulun [Review and Discussion on the Hypothesis that Taiwan Aboriginal Peoples Originate from the Dongyi]. Heilongjiang Minzu Congkan [Heilongjiang National Series] 2: 789o. 
Zhao, Zhijun. 2011. New archaeobotanic data for the study of the origins of agriculture in China. Current Anthropology 52: 295-306.

Zhongguo shehui kexueyuan kaogu yanjiusuo [Chinese Research Institute for Archaeology] (ed.).1997. Aohan Zhaobaogou—Xinshiqishidaijuluo [Zhaobaogou-A Neolithic Settlement]. Beijing: Zhongguo dabaike quanshu qubanshe. 